\title{
Fen Bilgisi Öğretmen Adaylarının Yenilenebilir Enerji Kaynakları Hakkındaki Düşünceleri
}

\author{
Ayşe Rabia BAŞARAN UĞUR ${ }^{1}$, Oktay BEKTAŞ² ve Emine GÜNERİ
}

\section{$\ddot{O} z$}

$\mathrm{Bu}$ çalışmanın amacı fen bilgisi öğretmen adaylarının yenilenebilir enerji kaynaklarına iliş̧kin düşüncelerinin belirlenmesidir. Bu çalışmada nitel araştırma desenlerinden biri olan fenomenoloji deseni kullanılmıştır. Çalışma grubunun seçiminde amaçl örnekleme yöntemleri içerisinde yer alan ölçüt örneklemesi tercih edilmiştir. Araştırmanın çalşşma grubunu 2018-2019 eğitim öğretim yll bahar döneminde Akdeniz bölgesinde yer alan bir devlet üniversitesinin eğitim fakültesinde fen bilgisi öğretmenliği programında eğitimine devam eden sekiz fen bilgisi öğretmen adayı oluşturmaktadır. Bu doğrultuda çalışmada, araştırmacılar tarafindan hazırlanan "Yenilenebilir Enerji Kaynakları Görüş̧e Formu” kullanılmıştır. Veriler 17/04/2019 ve 24/04/2019 tarihleri arasında toplanmıştır. Verilerin analizinde betimsel ve içerik analiz teknikleri birlikte kullanılmıştır. Elde edilen bulgulara göre öğretmen adaylarının yenilebilir enerji kaynaklarını daha çok sürekliliği devam eden, sonsuz üretim yapan, çevre dostu kaynaklar olarak tanımladıkları belirlenmiştir. Katılımcıların rüzgâr ve güneş enerijisini, en kullanışlı ve en yaygın yenilenebilir enerji kaynağı olarak ifade ettikleri ortaya çıkmıştır. Öğretmen adayları yenilenebilir enerji kaynaklarının doğayı koruma işlevi olduğunu ifade etmişlerdir. Öğretmen adayları bu kaynakların olumlu yönlerini ekonomik ve çevreye zararsız olması olarak belirtirken, yatırım maliyetinden dolayı olumsuz yönünün de olduğunu ifade etmişlerdir. Öğretmen adayları yenilenebilir enerji kaynaklarına ilişkin fakültelerde yeni bir ders açılması gerektiğini belirtmişlerdir. Bununla birlikte öğretmen adayları yenilenebilir enerji kaynaklarının alan gezileri ile öğrencilere öğretilmesi gerektiğini ifade etmişlerdir.

Anabtar Kelimeler: Yenilenebilir enerji, Yenilenebilir enerji kaynakları, Fen bilgisi ögretmen adayı.

Pre-service Science Teacher' Views Regarding Renewable Energy Sources

\section{Abstract}

This research attempts to identify the pre-service science teachers' views on renewable energy resources. The research deployed a phenomenological design, one of the qualitative research designs. The working group consisted of 8 pre-service science teachers who study science education at the education faculty of a state university in the Mediterranean region during the spring term of 2018-2019 academic year and who were selected by the criteria sampling, which is among the purposive sampling methods. In this context, the research employed a "Renewable Energy Resources Interview Form" prepared by the researchers as a data collection tool. The data were collected between 17/04/2019 and 24/04/2019. Descriptive and content analysis techniques were used during data analysis. Research results revealed that the pre-service science teachers defined renewable energy resources as ongoingness, endless production and environmentally friendly. The participants considered wind and solar energy as the most useful and most common renewable energy resources. The pre-service teachers also stated that renewable energy resources held the function of protecting nature. Moreover, the pre-service teachers noted the positive aspects of these resources as being economical and harmless to the environment, while a negative aspect due to the investment cost. The participants recommended that a new course be opened in faculties related to renewable energy resources, and that field trips be organized during the teaching process of the renewable energy resources.

Key Words: Renewable energy, Renewable energy sources, Pre-service science teacher

\section{Atıf İçin / Please Cite As:}

Başaran Uğur, A. R., Bektaş, O. ve Güneri, E. (2021). Fen bilgisi öğretmen adaylarının yenilenebilir enerji kaynakları hakkındaki düşünceleri. Manas Sosyal Araştırmalar Dergisi, 10(2), 828-850.

Geliş Tarihi / Received Date: 31.07.2020

Kabul Tarihi / Accepted Date: 08.01.2021

\footnotetext{
${ }^{1}$ Doktora öğrencisi- Erciyes Üniversitesi Eğitim Fakültesi, rabiabasaran1@hotmail.com - iD ORCID: 0000-0003-4654-7493

2 Doç. Dr. - Erciyes Üniversitesi Eğitim Fakültesi, obektas@erciyes.edu.tr - ID ORCID: 0000-0002-2562-2864

${ }_{3}^{3}$ Prof. Dr. - Erciyes Üniversitesi Eğitim Fakültesi, eguneri@erciyes.edu.tr - (DORCID: 0000-0002-3475-8229
} 


\section{Giriş}

Çevre, canlıların içinde yer aldığı, var olan yaşamsal faaliyetlerini sürdürdüğü koşul veya ortamlar olarak tanımlanmaktadır (Ilgar, 2007, s. 39). Cansaran ve Yıldırım'a (2010, s.19) göre çevre, bireyleri belirli bir zaman aralığında hem dolaylı hem de dolaysız şekilde etkileyen, bireylerin maddi ve manevi gelişimini destekleyen, yaşam koşullarını belirleyen coğrafik, toplumsal ve biyolojik etkinliklerin bütünüdür. Çevre eğitimi ise, bireylerin doğal ve yaşamsal ortamını algılamasını sağlayan, değer ve davranışlarını olumlu yönde etkilemek için gerçekleştirilen bir eğitimdir. Çevre eğitimi ise, bireylerin doğal ve yaşamsal ortamını algılamasını sağlayan, değer ve davranışlarını olumlu yönde etkilemek için gerçekleştirilen bir eğitimdir (Yangın ve Filik İşçen, 2013, s. 132). Çevre eğitimi, bireyin beşeri ve fiziksel sistemlerin karşllkklı etkileşimlerini algılanmasını ve öğrenmesini, geziler aracilğ̆ıla çevreye ilişkin öğrenmelerinin gerçekleşmesini, davranışlarını göz önüne alarak sorumluluk sahibi olmaşıı, çevreyi kullanma ve korumaya ilişkin duyarlılığının gelişmesini sağlamaktadır (Akınoğlu ve Sarı, 2007, s. 7). Çevre eğitiminde kullanılan kavramların çoğu, bireylerin zihinlerinde oluşan soyut kavramlar ve imajlardır. Bu nedenle çevre eğitimi yapısı gereği, kesin tanımlaması olmayan, zor kavramlardan oluşmaktadır. Bu kavramlardan biri çevre okuryazarlığıdır. Çevre eğitiminin en önemli amaçları arasında, çevreye ilişkin bilinçli davranışlar sergileyen ve çevre okuryazarlığ1 yüksek bireylerin yetiştirilmesi yer almaktadır (Gahl-Cole, 2007, s. 38; Moseley, 2000, s. 23; Sivek, 2002, s. 155). Çevre okuryazarllğı, çevresel sistemin sağlığını yenilemek, geliştirmek için bireylerin uygun davranışlar sergilemesidir (Disinger ve Roth, 1992, s. 2). Marcinkowski'ye (1991, s. 48) göre çevre okuryazarlığı, doğal çevreye saygı duyma, doğa için kaygılanma ve insanın çevreye olan etkilerini olumlu yönde geliştirme, çevreye ilişkin bilinç sahibi olma gibi davranışları geliştirmeyi içermektedir. Moseley (2000, s. 23) ise çevre okuryazarı bireylerin çevresinde yer alan kaynakları tanımaları ve onlar hakkında genel bir bilgi sahibi olmaları gerektiğini ifade etmiştir. Bu kaynaklardan biri olan enerji kaynakları ise son yıllarda çevreye ve insanlara olan etkileri nedeniyle daha fazla gündeme gelmiştir (Moseley, 2000, s. 23). Çünkü yeryüzünde yaşayan tüm insanlar rahat bir hayat sürdürebilme istekleri üzerine, sürekli olarak enerjiye ihtiyaç duymaktadırlar. Bu nedenle insanlığın, dünyanın geleceği ve sürdürülebilir kalkınma için fosil yakıtlara göre daha az çevresel etkisi olan yenilenebilir enerji kaynakları gündeme gelmiştir (Karanfil, 2009, s. 2; Karışan ve Topçu, 2016, s. 1348; Saatçioğlu ve Küçükaksoy, 2004, s. 20).

Yenilenebilir enerji, ekolojik dengeyi bozmadan ve telafisi olamayan çevre hasarlarına yol açmadan kuşaklar boyu sorunsuz devam edebilen bir enerijirir (Fırat, Sepetçioğlu ve Kiraz, 2012, s. 1213). Günümüzde yenilebilir enerji kaynaklarının güneş, deniz dalga, rüzgâr, hidrolik ve jeotermal enerji gibi türleri bulunmaktadır. Bu enerji türleri temiz-çevre dostu ve sürdürülebilir yaşam kavramına vurgu yapan enerji kaynaklarıdır (Bang, Ellinger, Hadjimarcou ve Traichal, 2000, s. 452; Upreti, 2004, s. 788). Bireylerin çevre konusundaki bilinçlendirme çalışmalarında; enerji tasarrufu, yaygınlaştırılması, kullanımı, hem ekonomik hem de temiz bir çevre açısından yenilenebilir enerji hakkında bilgilendirme çalısmalarının yapılması önemlidir (Bozdoğan ve Yiğit, 2014, s. 119; Öztürk, 2008, s. 26). Yenilenebilir enerji kaynaklarının yaygın olarak ve etkin bir biçimde kullanımı ile çevre kirliliği en az seviyeye inebilmekte ve ülkelerin geleceğine önemli katkılar sağlanmaktadır. Bu nedenle bireylerin yenilenebilir enerji kaynaklarına yönelik sahip oldukları düşüncelerinin belirlenmesi, onların geleceğe daha sağlam adımlar atılmasına yönelik, farkındalık yaratabilmek için gerekli olan bilgileri sunacaktır. Küçük yaşlardan itibaren çevresine karşı duyarlı, yenilenebilir enerjinin ne olduğunu, insanlığa faydalarını, kullanım alanlarını bilen ve çevre dostu olarak tanımlanan enerji kaynaklarına ilişkin yeterli bilgi düzeyine sahip bireylerin yetiştirilmesinde, öğretmenlerin üzerine önemli görevler düşmektedir (Liarakou, Gavrilakis ve Flouri, 2009, s. 121). Ögretmenler ise yenilenebilir enerji kaynaklarına ilişkin bilgileri çevre eğitimi dersi kapsamında, eğitim fakültesinde lisans düzeyinde almaktadırlar. Öğretmen adayları yenilenebilir enerjiye ilişkin olumlu düşüncelerini, mesleğe başladıklarında öğrencilerine yansıtarak, onlara öncülük edeceklerdir (Smati, 2004, s. 7). Dolayısıyla bu çalışma fen bilgisi öğretmen adaylarının, meslek hayatlarına başladıklarında ögrencilerinin yenilenebilir enerji kaynaklarına yönelik olumlu düşünce, tutum sağlamalarına katkıda bulunacaktır.

Alanyazın incelendiğinde yenilenebilir enerji kaynakları konusuna ilişkin farklı çalışmaların yer aldığı görülmektedir. Türkiye'de çalışmaların daha çok yenilenebilir enerji potansiyeli üzerinde gerçekleştirildiği görülmektedir (Bozkurt, 2008, s. 89; Öztürk, 2008, s. 26; Saatçioğlu ve Küçükaslan, 2004, s. 22; Turan, 2006, s. 33). Ayrıca fen bilgisi öğretmen adaylarının yenilenebilir enerji kaynaklarına yönelik bilgi düzeylerini belirlemeye (Karakaya Cırıt, 2017, s. 23), konuya ilişkin bilgilerin günlük yaşama aktarılmasına 
(Ertaş, Şen ve Parmasızoğlu, 2011, s. 181), yenilenebilir enerji farkındalı̆̆ını belirlemeye (Çakırlar, 2015, s.4) yönelik çalışmaların da alanyazında yer aldığı belirlenmiştir. Bununla birlikte alan yazında öğretmen adaylarının (Halder, Pietarinen, Nuutinen ve Pelkonen, 2010, s. 3060; Liarakou, Gavrilakis ve Flouri, 2009, s. 120; Zyadin, Puhakka, Ahponen, Cronberg ve Pelkonen, 2012, s. 79) ve öğrencilerin (Benzer, Karadeniz Bayrak, Dilek Eren ve Gürdal, 2014, s. 244; Çakırlar, 2015, s.4) yenilenebilir enerji kaynaklarına ilişkin tutumlarını inceleyen birçok çalışmanın yer aldığı görülmektedir. Fakat fen bilgisi öğretmen adayları ile nitel olarak gerçekleştirilen ve onların yenilenebilir enerji kaynaklarına ilişkin görüşlerini belirleyen çalışmaların sınırlı olduğu (Bıyıklı, 2018, s.2) ve bu çalışmaların daha çok yenilenebilir enerji kaynaklarına ilişkin örnekler, bu kaynakların avantajları, sürdürülebilir kalkınma üzerine yoğunlaştığı görülmektedir (Saraç ve Bedir, 2014, s. 20). Fakat bu kaynakların çevre ile ilişkisi, Türkiye açısından yenilenebilir enerji kaynaklarının önemi, kullanımı, toplum olarak bu kaynaklar hakkındaki bilgilerin yeterli olup olmaması, kaynakların tanıtılmasında öğretmenlerin rolü ve okuryazarlıkla ilişkisi hakkında yeterli derinlemesine çalışmanın olmadığı belirlenmiştir. Dolayısıyla bu çalışmanın alanyazına niteliksel olarak katkı sağlayacağı düşünülmektedir. Çalışmanın genel amacı fen bilgisi öğretmen adaylarının yenilenebilir enerji kaynaklarına yönelik görüşlerinin belirlenmesidir. Bu genel amaç doğrultusunda aşağıda yer alan sorulara cevap aranmıştır. Fen bilgisi öğretmen adaylarına göre:

1. Yenilenebilir enerji kaynakları (YEK) tanımı nasıldır?

2. YEK'e ilisskin örnekler nelerdir?

3. YEK algiları nelerdir?

4. En kullanışlı YEK nelerdir?

5. En yaygin kullanilan YEK nelerdir?

6. YEK'e yönelik etkinliğe katılım durumları nasıldır?

7. YEK'in işlevleri nelerdir?

8. YEK'in olumlu yönleri nelerdir?

9. YEK'in olumsuz yönleri nelerdir?

10. YEK'in ülkeye katkıları nelerdir?

11. YEK'i kullanan teknolojinin gelişmişliği nasıldır?

12. YEK tanıtımında öğretmenlerin rolü nelerdir?

13. YEK'e ilişkin yeni bir ders açılmalı mıdır?

14. YEK'e ilişkin verilen bilgilerin yeterlilik düzeyi nasıldır?

15. YEK öğretiminde kullanılacak yöntem ve teknikler nelerdir?

16. YEK'in geliştirdiği okuryazarlık türleri nelerdir?

17. YEK'e yönelik önerileri nelerdir?

\section{Yöntem}

\section{Araştırmanın Deseni}

Bu çalışmada nitel araştırma desenleri içerisinde yer alan fenomenoloji deseni tercih edilmiştir. Fenomenoloji bireylerin kendi deneyimlerinin bilinçliliğe nasıl dönüştürüldüğüne vurgu yapan, bireylerin günlük yaşam ve sosyal eylemleri ile ilgilenen, gerçeğin ne olduğuna dair bilgilerin ortaya çıkmasına firsat tanıyan ve gerçek nedir sorusuna yanıt arayan bir desendir (Merriam, 2013, s. 124). Bu desenin temelinde bireylerin yaşantıları ve tecrübeleri yer almaktadır. Dolayısıyla fenomenoloji deseninde önemli olan bireylerin yaşantıları ve olguya ilişkin tecrübeleridir (Göçer, 2013, s. 29). Fenomenoloji deseni, bireyler tarafindan bilinen fakat konuya ilişkin gerekli açıklamalar yapılırken, bilimsel olarak açık ve net ifadeler üretilemeyen olgu ya da olguların derinlemesine incelemeyi amaçlayan ve bu doğrultuda yorumlamalarda katılımcılardan zengin söylem ve düşünceler elde edilen bir araştırma desenidir (Yıldırım ve Şimşek, 2013, s. 89). Çalışmada öğretmen adaylarının yenilenebilir enerji kaynakları hakkında görüşlerinin belirlenmesi amaçlandı̆̆1 için ve öğretmen adaylarının yenilenebilir enerji kaynaklarına ilişkin daha önceden çevre dersi kapsamında bilgilere sahip olması yani konuya ilişskin geçmiş yaşantıları söz konusu olduğu için bu desen tercih edilmiştir.

\section{Çalışma Grubu}

Fenomenoloji deseni ile tasarlanmış çalışmalarda, olguyu açıklayacak bireylerin olguya ilişkin tecrübeleri olacak şekilde, olguyu doğru ve açı bir biçimde ortaya çıkarabilecek kişilerle çalışılması gerekmektedir (Creswell, 2007, s. 73; Patton, 2018, s. 95). Bu çalışmada, çalışma grubunun seçiminde amaçlı örnekleme yöntemleri içerisinde yer alan ölçüt örneklemesi tercih edilmiştir. Nitel araştırma düşüncesi içerisinde ortaya çıkan amaçlı örnekleme, olguların açıklanmasında ve keşfedilmesinde yararlı 
olan bir örnekleme yöntemidir. (Merriam, 2013, s. 124; Yıldırım ve Şimşek, 2013, s. 88). Ölçüt örnekleme ise araştırmacı tarafindan önceden belirlenmiş ölçüt ya da ölçütleri karşılayan durumlar üzerinde çalışılmasıdır (Yıldırım ve Şimşek, 2013, s. 88). Dolayısıyla, bu çalışmanın çalışma grubunu 2018-2019 eğitim-öğretim yllı bahar döneminde, Akdeniz bölgesinde yer alan bir devlet üniversitesinin eğitim fakültesinde dördüncü sınıf fen bilgisi öğretmenliği programında öğrenim gören sekiz fen bilgisi öğretmen adayı oluşturmaktadır. Çalışma grubunun seçiminde kullanılan ölçüt örneklemesindeki ölçüt, öğrencilerin yenilenebilir enerji kaynaklarına ilişkin bilgileri çevre eğitimi dersi kapsamında almış olmalarıdır Araştırmaya katılan öğretmen adaylarına dair demografik bilgiler Tablo 1'de gösterilmektedir.

Tablo 1. Fen Bilgisi Öğretmen Adaylarna İliskin Demografik Özellikler

\begin{tabular}{|c|c|c|c|}
\hline Katılımcilar & Cinsiyet & Yaş & Kod adlar1 \\
\hline 1.Kat1lımc1 & Kadın & 22 & Ayşe \\
\hline 2. Katılımc1 & Kadın & 23 & Fatma \\
\hline 3. Katılımc1 & Kadın & 22 & Zeynep \\
\hline 4. Katılımc1 & Erkek & 21 & Ali \\
\hline 5. Katılımc1 & Kadın & 23 & Aylin \\
\hline 6. Katılımc1 & Kadın & 23 & Asli \\
\hline 7. Katılımc1 & Erkek & 21 & Veli \\
\hline 8. Katılımc1 & Erkek & 22 & Hasan \\
\hline
\end{tabular}

Çalışmaya katılan öğretmen adaylarının kod isimleri ve cinsiyetleri Tablo 1'de görülmektedir. Çalışmaya beş kadın, üç erkek fen bilgisi öğretmen adayı katılmıştır.

\section{Veri Toplama Aracı}

Bu çalşşmada veri toplama aracı olarak yarı yapılandırılmış görüşme formu tercih edilmiştir. Yarı yapılandırılmış görüş̧me nitel araştırmalarda, katılımcıların algıladığı dünyayı ve düşünceleri kendi ifadeleriyle anlatmasıdır (Merriam, 2013, s. 125). Yarı yapılandırılmış görüşme, tam yapılandırılmış görüşmeler gibi katı bir görüşme türü değildir ve daha esnek bir yapıya sahiptir ve konuya ilişkin yeni fikirlere ulaşılması açısından kullanışlı bir görüş̧me türüdür (Karasar, 2013, s. 125). Bu çalışmada, konuya ilişkin farklı fikirlerin ortaya çıkarılması açısından yarı yapılandırılmış görüşme tercih edilmiştir. Bu doğrultuda çalıșmada, araștırmacı tarafından hazırlanan "Yenilenebilir Enerji Kaynakları Görüşme Formu" kullanılmıştır. Bu form hazırlanırken yurtiçinde ve yurt dışında yenilenebilir enerji kaynaklarına ilişskin gerçekleştirilen çalışmalar belirlenmiştir. Bu çalışmaların doğrultusunda araştırmacıların kullandığı ölçekler, anketler incelenmiş ve konuya ilişkin form hazırlanmıştır. Veri toplama aracının kapsam geçerliği için Erciyes Üniversitesi ve Kahramanmaraş Sütçü İmam Üniversitesi Fen Bilgisi Eğitimi Anabilim Dalı'nda görev yapan iki öğretim üyesine incelemesi için "Yenilenebilir Enerji Kaynakları Görüşme Formu" verilmiştir. Uzman görüşleri dikkate alındığında yarı yapılandırılmış görüşme formunun son halinin daha anlaşılır ve doğru ifadelerle hazırlanmasına dikkat edilmiştir. Örneğin "Yenilenebilir enerji kaynaklarının avantajları var mıdır? Varsa nelerdir?" ifadesi, daha anlaşıır ve açık olması amacıyla "Yenilenebilir enerji kaynaklarının olumlu yanları var mıdır? Varsa nelerdir?” şeklinde değiştirilmiştir. Ayrıca görüşme formunun son hali hazırlanırken, soru bütünlügünün sağlanması açısından soruların sıralamasına dikkat edilmiştir. Bu doğrultuda içeriğin bütünlük göstermesi ve daha anlaşılır olabilmesi açısından bazı soruların yerleri değiştirilmiştir. Bununla birlikte görüş̧me fen bilgisi öğretmen adayları ile yapılacağı için, onların geleceğin öğretmenleri olarak düşünüldüğünde, uzmanlardan gelen dönütler doğrultusunda, "Fakültede yenilenebilir enerji kaynaklarına ilişkin verilen bilgileri yeterli görüyor musunuz? Neden?" ve "Sizce yenilenebilir enerji kaynakları hangi okuryazarllğın geliştirilmesine katk1 sağlar?" ş̧eklinde sorular eklenmiştir. Eklemeler ve düzenlemeler sonucunda elde edilen görüşme formunun son halinde 17 soru yer almaktadır.

\section{Veri Toplama Süreci}

Verilerin toplanmasından önce, araştırmanın yapılacağı fakülteden gerekli olan izinler alınmıstır. Daha sonra ise fen bilgisi öğretmen adayları ile yüz yüze görüşülmüss, çalışmanın konusu ve amacı hakkında bilgiler verilmiştir. Bu bilgiler doğrultusunda fen bilgisi öğretmen adaylarından gönüllü olan öğrenciler belirlenmiştir. Gönüllü öğrenciler ile çalışmanın gerçekleştirilmesine yönelik bir planlama yapılmış ve veriler 17/04/2019 ve 24/04/2019 tarihleri arasında toplanmıştır. Çalışmaya katılan bireylerin düşüncelerini net bir şekilde ifade edebilmelerine yönelik konuşmalar yapılmış ve bu konuşmalar yaklaşık olarak 10 dakika sürmüştür. Görüşmeye başlamadan önce katılımcıya ses kaydının alınması gerektiği ifade edilerek verilen izin doğrultusunda, görüssmeye başlanmıştır. Görüşme sırasında, önemli noktalar 
araştırmacı tarafından not edilmiş ve öğretmen adaylarının söylemlerinin o sırada teyit edilmesine özen gösterilmiştir. Bu doğrultuda görüşme yaklaşık olarak 20-40 dakika arası sürmüştür. Görüşme sürecinde öğretmen adaylarını yönlendiren konuşmaların ya da söylemlerin olmamasına özen gösterilmiştir. Görüşme sonunda öğretmen adaylarının düşüncelerini bir kez daha teyit edebilmeleri adına, alınan ses kayıtları dinletilmiş, sorulan sorulara ilişkin eklemek istedikleri başka düşünceler olup olmadı̆̆1 sorularak, görüşme sonlandırılmıştır.

\section{Verilerin Analizi}

Fenomenoloji deseni ile gerçekleştirilen araştırmalarda elde edilen verilerin analizi, bireylerin yaşantılarını ve farklı kavramlara ilişkin düşüncelerini belirlemek amacıyla gerçekleştirilmektedir. $\mathrm{Bu}$ doğrultuda fenomenoloji deseni ile gerçekleştirilen bu çalışmanın veri analizinde içerik ve betimsel analiz tercih edilmiştir. İçerik analizi, temalar ya da kategoriler çerçevesinde elde edilen verileri kodlar halinde bir araya getirerek, bunları okuyucunun anlayabileceği bir biçimde düzenleyerek yorumlamaktır (Creswell, 2007, s. 73; Yıldırım ve Şimşek, 2013, s. 88). Çalışmada içerik ve kavramlar arasındaki ilişkiler derinlemesine incelendiği için ve çalışmaya katılan bireylere yöneltilen sorular "nasıldır" şeklinde bittiği için içerik analizi tercih edilmiştir. Betimsel analiz ise elde edilen verilerin betimlenmesi ve bu doğrultuda betimlemelerin açıklanarak yorumlanmasıdır (Merriam, 2013, s. 125; Yıldırım ve Şimşek, 2013, s. 90). Çalışmada betimsel analizinde kullanılma nedeni, sorulan soruların "ne" sözcüğü ile bitmesidir. Bu şekilde çalışmaya katılan bireylerden yüzeysel bilgiler elde edilmiştir. Çalışmada hem betimsel hem de içerik analizinin kullanılması ile analiz çeşitlendirilmesine gidilmiştir. Veri toplama aracı ile elde edilen veriler öncelikli olarak ses kayıt cihazından bilgisayar ortamına aktarılarak yazıya geçirilmiştir. Elde edilen verilerde katılımcıların gizliliği sağlanması açısından, araştırmacı tarafından belirlenen kısa isimler kullanılmıştır. Örneğin ilk kadın katılımcıya Ayşe, ilk erkek katılımcıya Ali ismi verilmiştir. Tüm bu ön hazırllklardan sonra ise analiz sürecine başlanılmışıtır. Bu doğrultuda veri seti soru sırasına göre cümle cümle okunmuştur. Okuma işlemi sırasında kod olarak belirlenen kelime ya da kelimelerin altı çizilmiştir. Daha sonra belirlenen tüm kodlar bir araya getirilerek kategoriler oluşturulmuş ve bütün kategoriler yenilenebilir enerji kaynakları teması altında analiz edilmiştir. Örneğin veri analizi sonucunda "jeotermal enerji, rüzgâr enerjisi ve hidrolik enerji" kavramları kod olarak belirlenmiş ve daha sonrasında ise bu kodlar "yenilenebilir enerji kaynaklarına ilişkin örnekler kategorisi" altında toplanmıştır. Bununla birlikte bir soruya yönelik olarak birden fazla kodun ortaya çıkarıldığı görülmüştür. Ayrıca kategoriler oluşturulurken, veri toplama aracında yer alan sorular göz önüne alınmıştır. Örneğin veri toplama aracında yer alan "Yenilenebilir enerji kaynaklarına ilişkin örnekler verir misiniz?" sorusuna ilişkin verilerin analizi sonucunda, kategori olarak "yenilenebilir enerji kaynaklarına ilişkin örnekler kategorisi belirlenmiştir. Bu şekilde çalışmada 17 kategori elde edilmiştir. Elde edilen verilerin analiz sonuçları tablo halinde, Erciyes Üniversitesi Fen Bilgisi Eğitimi Anabilim Dalı'nda görev yapan bir uzmana gösterilmiş ve uzman dönütü alınmıştır. Uzmandan gelen dönütler doğrultusunda tablolarda yeniden düzenlemeler gerçekleştirilmiştir. Ayrıca Milles ve Huberman (2016) tarafindan ortaya atılan ve nitel araştırmalarda geçerli olan uyum indeksi formülü kullanılarak, araştırmacı ve uzman arasındaki uyum yüzdesi belirlenmiştir. Uyum yüzde formülü: "P=[Na/(Na+ Nd)x100]" olarak ifade edilmektedir. Burada yer alan $\mathrm{P}$ uyum yüzdesini, Na uyum miktarını, Nd ise uyuşmazlık miktarını belirtmektedir. Yıldıım ve Şimşek (2013) yapılan çalışmalarda uyum yüzdesinin en az \%70 ve üzeri olarak hesaplanması gerektiğini ifade etmektedir. Yapılan bu çalssmanın uyum yüzdesi $(\mathrm{Na}=92, \mathrm{Nd}=11) \% 89$ olarak hesaplanmıştr.

\section{Geçerlik ve Güvenirlik}

Nitel olarak gerçekleştirilen çalışmalarda geçerliliğin ve güvenirliğin sağlanması adına iç geçerlik, dış geçerlik, iç güvenirlik ve diş güvenirlik olmak üzere dört farklı faktörün incelenmesi ve ifade edilmesi gerekmektedir (Merriam, 2013, s. 140). İç geçerlik çalışmanın inandırıcıllı̆̆ını, dış geçerlik ise nitel çalışmalarda daha çok aktarılabilirliği ortaya koymaktadır. İç güvenirlik ise çalışmanın bölümleri arasında ve analiz sonuçlarının tutarlığı, dış güvenirlik ise çalısmanın teyit edilebilmesi ile ilgilidir (Yıldırım ve Şimşek, 2013, s. 75).

İç geçerlik faktörünün nitel çalışmalardaki karşılı̆̆ inandırıcı olmasıdır ve uzun süreli etkileşim, çeşitleme ve katılımcı teyidi gibi adımları içermektedir (Arastman, Öztürk Fidan ve Fidan, 2018, s. 51). Çalısmada uzman görüşü iki şekilde alınmıştır. İlk adım olarak veri toplama aracında yer alan sorular bir uzmana gösterilmiştir. Uzman tarafindan gelen dönütler doğrultusunda veri toplama aracının son hali alınmıştır. İkinci adımda ise verilerle yapılan analizler, bulgular şeklinde yazılmadan uzmana incelettirilmiştir ve bu doğrultuda uzman dönütleri dikkate alınarak gerekli düzeltmeler yapılmıştır. 
Katılımcı teyidi için görüşme sırasında, katıllımcıların ifadeleri araştırmacı tarafından tekrar edilerek alınmıştır. Bununla birlikte görüşme sonrasında katılımcılara ses kayıtları dinleterek, görüşmeden elde edilen veriler onaylatılmıştır. Çeşitleme aşamasında ise veri analizinde betimsel ve içerik analizi birlikte kullanılarak veri analiz çeşitlemesi yapılmıştır. Ayrıca bulgular bölümünde, her koda ilişkin olarak en az bir katılımcının doğrudan alıntısına yer verilmiştir. Tüm bunlardan dolayı çalışmanın iç geçerliği artırılmıştır.

Dış geçerlik faktörünün nitel çalışmalardaki karşılığ aktarılabilirliktir ve amaçlı örneklemenin kullanılması, ayrıntılı betimlemelerin yapılması aşamaları içermektedir (Başkale, 2016, s. 24). Bu çalışmada da amaçlı örnekleme türü içerisinde yer alan ölçüt örnekleme tercih edilmiştir. Ayrıntılı betimleme aşamasında ise çalışmaya yönelik olarak farklı adımlar izlenmiştir. Öncelikli olarak çalışmanın giriş kısmında, çalışmaya ilişkin teorik bilgiler detaylı bir şekilde verilmiştir. Çalışmanın yöntem bölümünde ise çalışmanın deseni, katılımcılar, veri toplama aracı, veri toplama süreci ve verilerin analizi detaylı bir şekilde incelenmiştir. Bulgular bölümü ise yorum yapılmadan sunulmuştur. Son olarak, tartsşma ve sonuç bölümünde elde edilen bulgular alanyazın ile ilişkilendirilmiş ve diş geçerlik artırılmıstır.

İç güvenirliğin sağlanması bulguların var olduğu gibi okuyuculara sunulması ve kodlama tutarlıliğının sağlanmas1 gerekmektedir (Arastman, Öztürk Fidan ve Fidan, 2018, s. 56; Başkale, 2016, s. 24). Bu çalışmada da elde edilen verilerin analizi sonucunda ortaya çıan bulgular, yorum yapılmadan yazılmış ve bulgular bölümünde sunulmuştur. Bunun için sık sık doğrudan alıntılara yer verilmiştir. Kodlama tutarlığında ise araştırmacı tarafindan oluşturulan kodlar ve kategoriler uzmana gösterilmiştir. Uzman tarafından gerçekleştirilen kontroller sonucunda, araştırmacı ve uzman fikir birliğine varmıstır. Dolayısıyla, bu izlenen adımlarla birlikte çalışmanın iç güvenirliği de artırılmıştır.

Dış güvenirlik için ise araştırma sonuçları verilerle karşılaştırılmıştır. Bu doğrultuda ise uzman kontrolüne gidilmiştir. Çalışmanın analiz, bulgular, tartışma ve sonuç bölümlerinin birbiri ile tutarlı olması sağlanmıştır. Bu doğrultuda çalışmanın dış güvenirliği de artırılmıştır.

\section{Bulgular}

\section{"Yenilenebilir enerji kaynakları tanım" kategorisine yönelik bulgular}

Tablo 2. "Yenilenebilir Enerji Kaynaklan Tanmm” Kategorisindeki Katılımcı Görïsleri

\begin{tabular}{|c|c|c|c|c|c|c|c|c|c|}
\hline Kodlar & $\mathrm{F}$ & Ayşe & Fatma & Zeynep & Ali & Aylin & Asli & Veli & Hasan \\
\hline Sürekliliği devam eden kaynak & 4 & + & & + & & & + & & + \\
\hline Çevre dostu kaynak & 3 & & & & & + & + & & + \\
\hline Uzun süreli kullanılan kaynak & 3 & & & & + & + & & & + \\
\hline Doğal süreçlerden elde edilen kaynak & 2 & + & + & & & & & & \\
\hline Fosil yakıtlara bağımlılığı azaltma & 2 & & & & & + & & & + \\
\hline Kendini yenileyen kaynak & 1 & & & + & & & & & \\
\hline Doğa olaylarını faydaya çevirme & 1 & & & & + & & & & \\
\hline $\begin{array}{l}\text { Tüketilen } \quad \text { kaynakları doğaya } \\
\text { kavuşturma }\end{array}$ & 1 & & & & & & & + & \\
\hline
\end{tabular}

Tablo 2'de fen bilgisi öğretmen adaylarının yenilenebilir enerji kaynaklarına yönelik dokuz farklı tanım yaptıkları görülmektedir. Sürekliliği devam eden kaynak tanımını yapan dört öğretmen adayı bulunmaktadır. Öğretmen adaylarından Aslı düşüncesini “....yenilenebilir enerji kaynakları, kullanım sürekli olan enerji kaynaklarıdır." şeklinde ifade etmiştir. Üç katılımcı çevre dostu kaynak olarak tanımlarken, benzer şekilde üç katılımcı da uzun süreli kullanılan kaynak olarak tanımlamışlardır. Tablo 2'de de görüldüğü gibi iki katılımcı yenilenebilir enerji kaynaklarının doğal süreçlerden elde edilen kaynaklar olduğunu düşünmüşler ve konuya ilişkin düşüncesini Ayşe “...Doğal süreçler var olan enerji” olarak belirtmiştir. Yenilenebilir enerji kaynağının tanımını fosil yakıtlara bağımlılığı azaltma olarak açıklayan iki katılımc1 bulunmaktadır. Bu katılımcılardan Hasan düşüncesini “...Bitmek üzere olan fosil yakıtlardan kurtulmamıฆి sağlayan kaynaklardır." şeklinde açıklamıştır. Yenilenebilir enerji kaynaklarının tanımını yaparken Zeynep kendini yenileyen kaynak olarak açıklarken; Ali ise doğa olaylarını faydaya çevirme işi olarak tanımlamıştır. Benzer şekilde Veli Yenilenebilir enerji kaynaklarının tanımını tüketilen kaynakları doğaya kavuşturma olarak yapmıştır. Veli bu düşüncesini "Yenilenebilir enerji kaynaklar bižim doğada tüketmis olduğumuz enerji kaynaklarmin tekrar doğaya ve canlulara kavuşturulması için oluşturulan sistemdir...” şeklinde belirtmiştir. 


\section{"Yenilenebilir enerji kaynakları örnekler" kategorisine yönelik bulgular}

Tablo 3. "Yenilenebilir Enerji Kaynaklarna İliskin Örnekler” Kategorisindeki Katılımc Görüsleri

\begin{tabular}{|c|c|c|c|c|c|c|c|c|c|}
\hline Kodlar & $\mathrm{f}$ & Ayşe & Fatma & Zeynep & Ali & Aylin & Asl1 & Veli & Hasan \\
\hline Rüzgâr & 8 & + & + & + & + & + & + & + & + \\
\hline Güneş & 7 & & + & + & + & + & + & + & + \\
\hline Hidrolik & 6 & + & & + & & + & + & + & + \\
\hline Jeotermal & 6 & + & + & + & & + & + & & + \\
\hline Biyokütle & 5 & + & + & + & & & + & + & \\
\hline Hidrojen & 3 & + & & + & & + & & & \\
\hline Gelgit & 3 & & & & + & & + & + & \\
\hline Ses & 1 & & & & + & & & & \\
\hline
\end{tabular}

Tablo 3’te öğretmen adaylarının yenilenebilir kaynaklara ilişkin verdikleri örnekler yer almaktadır. Katılımcılar tarafından daha çok tercih edilen örnekler rüzgâr ve güneş enerjisi, en az tercih edilen örnek ise ses enerjisidir. Zeynep konuya ilişkin daha fazla örnek vermiş ve bu örnekleri ifade ederken " $B u$ kaynaklar hidrojen enerjisi, rü̈gâr enerjisi, güneş enerjisi olabilir. Bunun dışıda, biyokütle enerjisi, jeotermal enerji, bidrolik enerjisidir." açıklamasını yapmıştır. Bununla birlikte, Aslı "Yenilenebilir enerji kaynaklarına güneş, rü̈ggâr, dalga olabilir, bidroelektrik, jeotermal ve biyokütle enerjilerini örnek olarak verebilirim." Yenilenebilir enerji kaynaklarına yönelik ses enerjisini örnek olarak veren, Ali düşüncesini “... ses enerjïini kullanma olayları vardı hatırladı̆̆m kadarıyla. Sesle ilgili ses dalgalarıla falan enerji üretimi..." olarak ifade etmiştir.

\section{"Yenilenebilir enerji kaynaklarına yönelik algılar" kategorisine yönelik bulgular}

Tablo 4. "Yenilenebilir Enerji Kaynaklarna Yönelik. Algılar” Kategorisindeki Katılıma Görüsleri

\begin{tabular}{|c|c|c|c|c|c|c|c|c|c|}
\hline Kodlar & $\mathrm{f}$ & Ayşe & Fatma & Zeynep & Ali & Aylin & Asli & Veli & Hasan \\
\hline Yetersiz & 6 & + & & + & + & + & + & + & \\
\hline
\end{tabular}

Tablo 4'de görüldüğü üzere öğretmen adaylarının çoğu yenilenebilir enerji kaynakları hakkında yetersiz algıya sahip olduklarını ifade eden altı katılımcı bulunmaktadır. Yenilenebilir enerji kaynakları hakkında bireylerin yetersiz algıya sahip olduğunu düşünen Zeynep bireylerin araştırmayı sevmediğini belirterek, düşüncesini "Biz toplum olarak okumayn sevmiyoruz. Yeterli yayn, dergi var midır bilmiyorum ama okuma alışkanlı̆̆mız olmadı̆̆ için bireyler olarak yeterli bilgi sabibi olamuyoruz: Belki bu konuda afişler asılyyor olabilir üniversitede ama görsek de görmemezlikten geliyoruz. Birinin gelip bu konuda bilgi vermesini bekliyoru₹. Bu nedenle de bilgi sabibiyiz diyemiyorum." şeklinde belirtmiştir. Yenilenebilir enerji kaynaklarına ilişkin bireylerin yeterli alg1ya sahip olduğunu düşünen Fatma düşüncesini "Toplum genel olarak barajlarn, güneş enerjilerinin, rüzgâr tribünlerinin ne işe yaradiğm bilmekte hatta çoğunluk kendi evrelerinde güneş enerjisinden sucak su elde etmektedir." şeklinde açıklamıştır.

\section{“En kullanışlı yenilenebilir enerji kaynakları” kategorisine yönelik bulgular}

Tablo 5. "En Kullanışl Yenilenebilir Enerji Kaynakları” Kategorisindeki Katılımı Görüsleri

\begin{tabular}{|c|c|c|c|c|c|c|c|c|c|}
\hline Kodlar & $\mathrm{f}$ & Ayşe & Fatma & Zeynep & Ali & Aylin & Asli & Veli & Hasan \\
\hline Güneş & 8 & + & + & + & + & + & + & + & + \\
\hline Rüzgâr & 5 & + & & & + & + & + & & + \\
\hline Hidroelektrik & 3 & + & & & & & & + & + \\
\hline Jeotermal & 1 & & & & & & & & + \\
\hline Gelgit & 1 & & & & & & & + & \\
\hline
\end{tabular}

Tablo 5’te öğretmen adaylarına göre Türkiye için en kullanışlı yenilenebilir enerji kaynak örnekleri yer almaktadır. Katılımcıların en kullanışlı olarak gördüğü yenilenebilir enerji kaynağı güneş ve rüzgâr enerjisidir. Öğretmen adayları tarafından en az değinilen yenilenebilir enerji kaynağı ise jeotermal ve gelgit enerjisidir. 


\section{"En yaygın kullanılan yenilenebilir enerji kaynakları" kategorisine yönelik bulgular}

Tablo 6. "En Yaygun Kullanulan Yenilenebilir Enerji Kaynaklarn" Kategorisindeki Katılıma Görüsleri

\begin{tabular}{lccccccccc}
\hline Kodlar & $\mathrm{f}$ & Ayșe & Fatma & Zeynep & Ali & Aylin & Asli & Veli & Hasan \\
\hline Rüzgâr & 7 & + & & + & + & + & + & + & + \\
Güneş & 6 & + & + & & + & + & & + & + \\
Hidroelektrik & 3 & + & & & & & + & & + \\
Jeotermal & 2 & + & & & & & & & + \\
\hline
\end{tabular}

Yukarıda yer alan Tablo 6'da öğretmen adaylarının Türkiye'de en yaygın şekilde kullanılan yenilenebilir enerji kaynaklarına ilişkin örnekleri yer almaktadır. Bu kategoride yedi katılımcı rüzgâr, altı katılımcı güneş enerjisinin Türkiye'de en yaygın kullanılan enerji kaynakları olduğunu ifade etmişlerdir. Bu kaynaklara üç katılımcı hidroelektrik, iki katılımcı ise jeotermal enerji örneğini vermiştir.

"Yenilenebilir enerji kaynaklarına ilişkin etkinliğe katılım" kategorisine yönelik bulgular

Tablo 7. "Yenilenebilir Enerji Kaynaklarna İlişkin Etkinliğe Katılım” Kategorisindeki Katılmmu Görüsleri

\begin{tabular}{lccccccccc}
\hline Kodlar & $\mathrm{f}$ & Ayşe & Fatma & Zeynep & Ali & Aylin & Aslı & Veli & Hasan \\
\hline Hayır & 6 & + & + & & + & + & + & + & \\
Evet & 2 & & & + & & & & & \\
\hline
\end{tabular}

Tablo 7'de ögretmen adaylarının yenilenebilir enerji kaynakları ile ilgili olarak daha önce herhangi bir etkinliğe katılıp katılmadıklarına dair kodlar yer almaktadır. Yenilenebilir enerji kaynaklarına ilişkin gerçekleştirilen herhangi bir etkinliğe katılmadıklarını ifade eden altı katılımcı bulunmaktadır. Etkinliğe katılmadığını belirten Ali düşüncelerini "Herbangi bir etkinliğe maalesef katılmadım." şeklinde ifade etmiştir. Tablo 8'de görüldüğü üzere, yenilenebilir enerji kaynaklarına ilişkin etkinliğe sadece iki katılımc1 katıldıklarını belirtmişlerdir. Konuya ilişkin olarak Hasan düşüncelerini "Katıldım. İceriğ rü̈ggâr gü̈lü ve barajdı. Bu çevrede ikisi de var. Oralara gittik. Hoca orada güzel bilgiler verdi." olarak açıklamıştır.

\section{"Yenilenebilir enerji kaynaklarının işlevi" kategorisine yönelik bulgular}

Tablo 8. "Yenilenebilir Enerji Kaynaklarmm İslevi" Kategorisindeki Katıllmo Görüsleri

\begin{tabular}{|c|c|c|c|c|c|c|c|c|c|}
\hline Kodlar & $\mathrm{f}$ & Ayşe & Fatma & Zeynep & Ali & Aylin & Asl1 & Veli & Hasan \\
\hline Doğayı korumak & 4 & & & & + & + & + & & + \\
\hline Yaşamı kolaylaştırmak & 2 & & & + & & & + & & \\
\hline Artan nüfus gereksinimini karşılamak & 2 & & & & & & & + & + \\
\hline Enerji dönüşümünü sağlamak & 2 & + & + & & & & & & \\
\hline
\end{tabular}

Tablo 8'de görüldüğü üzere dört katılımcı yenilenebilir enerji kaynaklarının görevinin doğayı korumak olduğunu belirtmişlerdir. Ali bu yöndeki düşüncesini “...doğann zarar görmemesi, en büyü̈k işlev bu zaten." olarak açıklamıştır. Bu kaynakların yaşamı kolaylaştırdığını düşünenlerden Zeynep düşüncesini "Insanlarn yasamin kolaylasstrri. Yaz aylarnda bizim evin çatısinda günes enerjisi var. Uzun süreden beri kullanyoruz: Her zaman

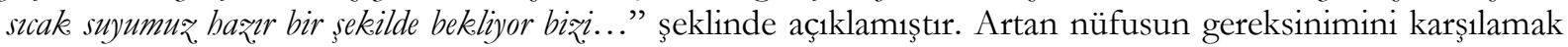
için yenilenebilir enerji kaynaklarının kullanıldığını belirtenlerden (f:2) Veli düşüncesini "Artan nüfusa bir cevap vermemiz, gereklidir. Bu cevap ise yenilenebilir enerji kaynaklarıdr. Şimdi nüfusumuz arttğ için kaynaklarmız,

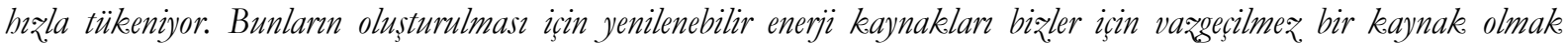
zorundadır..." olarak ifade etmiştir. Son olarak, yenilenebilir enerji kaynaklarının enerji dönüşümünü sağlama görevi (f:2) olduğunu belirten katıllımcilardan Ayșe ise düşüncesini "başka enerji kaynaklarnna çevrilmesi”" şeklinde belirtmiştir. 


\section{“Yenilenebilir enerji kaynaklarının olumlu yönleri” kategorisine yönelik bulgular}

Tablo 9. "Yenilenebilir Enerji Kaynaklarnm Olumlu Yönleri” Kategorisindeki Katılımo Görüsleri

\begin{tabular}{|c|c|c|c|c|c|c|c|c|c|}
\hline Kodlar & $\mathrm{F}$ & Ayșe & Fatma & Zeynep & Ali & Aylin & Asli & Veli & Hasan \\
\hline Ekonomik olmas1 & 6 & & + & + & & + & + & + & + \\
\hline Çevreye zararsız olması & 3 & & & & & + & + & & + \\
\hline Dış ülkelere bağımlı olmaması & 2 & & & + & & & & + & \\
\hline Kırsal alanlara destek olması & 1 & + & & & & & & & \\
\hline Temiz kaynak olması & 1 & & & + & & & & & \\
\hline Tükenme riskinin olmamas1 & 1 & & & + & & & & & \\
\hline Atık üretmemesi & 1 & & & + & & & & & \\
\hline Bilgiye ulaşmayı kolaylaştırması & 1 & & & & + & & & & \\
\hline Enerjiyi kısa sürede oluşturması & 1 & & & & & & & + & \\
\hline Uzun vadede kazanç sağlaması & 1 & & & & & + & & & \\
\hline Görsel şölen olması & 1 & & & & & & & & + \\
\hline
\end{tabular}

Tablo 9'da fen bilgisi öğretmen adaylarının yenilenebilir enerji kaynaklarının olumlu yönlerine ilişkin kodları yer almaktadır. Altı katılımcı yenilenebilir enerji kaynaklarının ekonomik olduğu belirtmiş ve Fatma

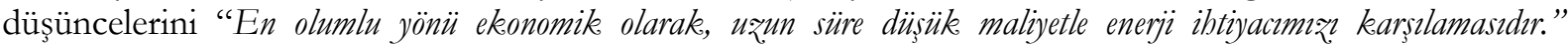
şeklinde ifade etmiştir. Üç katılımcı yenilenebilir enerji kaynaklarının çevreye zararsız olduğunu belirtmiş ve bu katılımcılardan Aylin düşüncesini "En büyüle olumlu yan çevreyi kirletmemesidir." şeklinde belirtmiştir. Ayrıca iki katılımcı bu kaynakların dış ülkelere bağımlı olmamasına değinmiştir. Zeynep düşüncesini "Bir doğal gazı Rusya'dan alyyoruz: Rusya'yla ilișkimiz iyi olduğunda bir sorun olmuyor. Ama ülkeler arası ufak bir kerizde doğal gaž almamı etkileniyor. Bu da aslinda ülkemizฺ Rusya'ya bağıml kellyor. İste yenilenebilir enerji kaynaklar bunu engelliyor. Her ülke basska ülkelere mubtac olmuyor bana göre.” olarak ifade etmiştir. Yenilenebilir enerji kaynaklarının kırsal alanlara destek olduğu belirten Ayşe düşüncesini "kersal alanlarda elektrik enerjisini kullanmayı sağlayan günes panellerimiz var. Bunun baricinde barajlarmı olsun, su elektrik bunlar sağlayacak firsatlarmmı var." şeklinde belirtmiştir. Konuya ilişkin olarak yenilenebilir enerji kaynaklarının temiz kaynak olması, tükenme riskinin olmaması ve atık üretmemesine değinen fen bilgisi öğretmen adayı Zeynep düşüncesini şu şekilde ifade etmiştir: "Bunlar temiz enerji kaynağıder ve çeure dostudur. kaynaklar gibi tükenme riski yoktur. Dünya var olduğu sürece yenilenebilir enerjillerde var olacak sonucta. Diğer kaynaklar atck üretir. Bu da çevreyi olumsur. etkiler sonucta. Ama yenilenebilir enerji kaynaklar atık madde üretmez:" Yenilenebilir enerji kaynaklarının bilgiye ulaşmayı kolaylaştırdığına değinen Ali düşüncesini şu şekilde açıklamıştır: "İnsanlar bilgìe aş ve

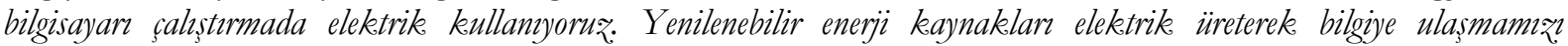
sağhlyor." Bu kaynakların enerijyi kısa sürede oluşturduğuna değinen Veli düşüncesini "Bu yenilenemeyen enerji kaynaklar çok uzun süreglerde olusuyor. Fakat yenilenebilir enerji kaynaklar daba kisa sürede olușmaktadrr." şeklinde ifade etmiştir. Yenilenebilir enerji kaynaklarının çevreye etkisini görsel şölen olarak nitelendiren Hasan, düşüncesini “Ashnda görsel açıdan da çevreye güzellike kazandirr. Mesela rüzgar tribünleri, barajlar. Ben mesela ne zaman rüzgar tribünleri görsem hayran bayran iə̨lerim. Cok güzel gözü̈kür uzaktan” şeklinde ifade etmiştir.

\section{"Yenilenebilir enerji kaynaklarının olumsuz yönleri” kategorisine yönelik bulgular}

Tablo 10. "Yenilenebilir Enerji Kaynaklarmın Olumsuz Yönleri” Kategorisindeki Katılımcı Görïsleri

\begin{tabular}{|c|c|c|c|c|c|c|c|c|c|}
\hline Kodlar & $\mathrm{F}$ & Ayşe & Fatma & Zeynep & Ali & Aylin & Asli & Veli & Hasan \\
\hline Yatırım maliyeti & 5 & + & & + & & + & + & + & \\
\hline Canlilara zarar verme & 4 & + & & & + & + & + & & \\
\hline Tarım arazilerinin işgali & 3 & + & & + & & + & + & & \\
\hline İklimi olumsuz etkileme & 2 & & + & + & & & & & \\
\hline Tarımı olumsuz etkileme & 2 & + & & & + & & & & \\
\hline Bazı aylarda verim düşüklüğü & 1 & & + & & & & & & \\
\hline Doğal dengeyi bozma & 1 & & & + & & & & & \\
\hline Doğanın her etkiye tepki vermesi & 1 & & & & & & & + & \\
\hline Atık su oluşumu & 1 & + & & & & & & & \\
\hline Yapımında insan faktörlü kirlilik & 1 & & & + & & & & & \\
\hline Olumsuzluk yoktur & 1 & & & & & & & & + \\
\hline
\end{tabular}

Tablo 10'da katılımcılar tarafindan belirtilen yenilenebilir enerji kaynaklarının olumsuz yönleri gösterilmektedir. Bu kaynaklara yapılan yatırımın maliyetli olduğunu belirten beş katılımcıdan birisi olan Zeynep konu hakkındaki düşüncesini şu şekilde açıklamıştır. “...maliyetlidir. O yüzden bence toplum biraz uz̧ak duruyor..." Tarım arazilerinin işgaline değinen üç ögretmen adayı bulunmaktadır ve Aslı ise düşüncelerini ifade ederken "yenilenebilir enerji kaynaklar tarm arą̧ileri alanlarnna yapıldiğ için, tarma da biraz engel olduğunu 
düs̆̈̈nüyorum." açıklamasında bulunmuştur. İki katılımcı bu kaynakların canlılara zarar verdiğini ifade etmiş ve Aslı düşüncesini şu şeklide belirtmiştir: "Birçok kușun ölümüne sebep oluyor. Güneș panelleri ısı yaydğğ için kuşun yanmasma neden oluyor. Aynca bir dergide çok şiddetli rü̈gâr olduğu zaman, kuşlarn türbinlerin kenarlarna çarparak öldüklerini okumustum." Yenilenebilir enerji kaynaklarının iklime olumsuz etkisi olduğu ifade eden iki katılımc bulunmaktadır ve Fatma düşüncesini “...Kurak iklime sabip yerlerde kurulan barajlar o gevvrenin iklimine nemli havast ile etkiler ve o bölgede kurak, hava seven bitki ve hayvan türlerini olumsuz, etkileyebilir. Mesela bunun örneği Urfa'da olmustu. Urfa'ya baraj kurulduktan sonra oradaki fistık üretimi azalmuşst çünkü fistıklar kurak havada yassıyordu." olarak açıklamıştır. Ayrıca iki katılımcı bu kaynakların tarımı olumsuz etkilediğini belirtmiş ve Ayşe düşüncesini şu şekilde açıklamıştır: “...tarm arąileri verimli topraklardan olusabilir. Bu nedenle kurulduğunda verimli topraklarmı yok olabilir. Böylelikle tarm faaliyetlerimiz olumsur. sekilde etkilenir..." $\mathrm{Bu}$ kaynakların doğal dengeyi bozduğuna değinen Zeynep ise düşüncelerini şu şekilde açıklamıştır: "baraj bulunan yerlerin havasmm eskiye göre kiyaslandiğmda değ̈stiğini görïyoru: Bu da aslinda doğal dengeyi bozuyor diyebilirim..." Doğanın her etkiye bir tepki verdiğini düşünen Veli şu ifadeyi kullanmıştır: "Doğaya yapılan her etki bir tepki gösterecektir sonuçta..." Ayrıca atık su oluşumunun yenilenebilir enerji kaynaklarının olumsuz yönü olduğuna değinen Ayşe düşüncelerini ifade ederken “...Mesela Jeotermal enerji yenilenebilir enerji kaynăğdir. Ama onun elektrik üretmesi esnasinda kullandiğmı zaman, atı sular çevreye zarar verebiliyor..." açıklamasında bulunmuştur. Yenilenebilir enerji kaynaklarının olumsuz bir yönü bulunmadığını ifade eden

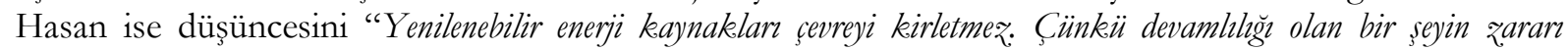
olmaz. Adv üstünde cevre dostu kaynaklarder diye tammlyoruz:" olarak belirtmiştir.

\section{"Yenilenebilir enerji kaynaklarının ülkeye katkıları" kategorisine yönelik bulgular}

Tablo 11. "Yenilenebilir Enerji Kaynaklarmın Ülkeye Katkıları" Kategorisindeki Katılımcı Görüsleri

\begin{tabular}{|c|c|c|c|c|c|c|c|c|c|}
\hline Kodlar & $\mathrm{F}$ & Ayşe & Fatma & Zeynep & Ali & Aylin & Asl1 & Veli & Hasan \\
\hline Ekonomik & 6 & + & + & + & + & + & + & & \\
\hline Dış ülkelerden bağımsız olması & 3 & & + & + & & + & & & \\
\hline İhracat yapilması & 2 & & & & & & & + & + \\
\hline Hastalıkları önlemesi & 2 & & & & & & & + & + \\
\hline Turist çekmesi & 1 & & & & & & & & + \\
\hline
\end{tabular}

Yukarıdaki tabloda yenilenebilir enerji kaynaklarının ülkeye katkılarına yönelik kodlar yer almaktadır. Beş katılımcı ülkeye ekonomik olarak avantaj sağladığını belirtmiş ve Zeynep düşüncesini "Mesela belki çok maliyetli bir şekilde devlet yapturyor rüzgâr tribünlerini. Ama daba sonra maliyeti olmuyor gibi bir șey. Ya da biz evimizin çatsinna güneş enerjisi yapturyoru₹: Illk yapturrken belki baya para barcanyyor ama sonra ücretsiz. kullanyoruz. Faturalar düs̈̈̈yor." şeklinde belirtmiştir. Yenilenebilir enerji kaynaklarının dış ülkelerden bağımsız olmasına değinen iki katılımcı bulunmakta ve bu katıllımcilardan Zeynep düşüncesini “... devlet başka devlete borçlanarak kaynağr almıyor..." şeklinde açıklamıştır. İhracat kavramına değinen ve yenilenebilir enerji kaynaklarının sağlık açısından ülkeye katk1 sağladığını belirten Veli düşüncesini “...İhracat yönünden katkalar varder. Enerji kaynaklarmin fazlahğ baska ülkelere satılabilir. Ayrıca kaphcalarmız var. Jeotermal enerjiye yönelik. Oralara giderek, daha sağhlkh bir bedene kavusulabilir.” şeklinde açıklamaktadır. Bu kaynakların ülkeye turist çektiğini belirten Hasan ise düşüncesini şu şekilde açıklamaktadır: “... Ayrica jeotermal olan yerlerde kaphlıalar kurularak turist cekilebilir..."

\section{"Yenilenebilir enerji kaynaklarını kullanan teknolojinin gelişmişliği” kategorisine yönelik bulgular}

Tablo 12. "Yenilenebilir Enerji Kaynaklarmı Kullanan Teknolojinin Gelismișliğ̈" Kategorisindeki Katıllma Görüsleri

\begin{tabular}{|c|c|c|c|c|c|c|c|c|c|}
\hline Kodlar & $\mathrm{F}$ & Ayşe & Fatma & Zeynep & Ali & Aylin & Asli & Veli & Hasan \\
\hline Gelişmemiş & 5 & & & & + & + & + & + & + \\
\hline Kısmen gelişmiş & 2 & + & & + & & & & & \\
\hline Gelişmiş & 1 & & + & & & & & & \\
\hline
\end{tabular}

Tablo 12'de yenilenebilir enerji kaynakları teknolojisinin gelişmişliğine dair kodlara yer verilmiştir. Beş katılımcı yenilebilir enerji kaynaklarını kullanan teknolojinin gelişmediğini belirtmiş ve Ali konu hakkında "Batı kendisini dış dünyaya güzel insanlar, bilinçli ve anlayışl olarak empoze etmiş. Bižim bilim adamlarmız mesela o

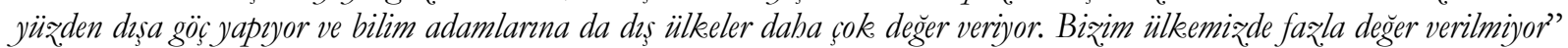
düşüncesini belirtmiştir. Yenilenebilir enerji kaynaklarını kullanan teknolojinin kısmen geliştiğini ifade eden üç öğretmen adayı bulunmaktadır. Bu öğretmen adaylarından Zeynep “...çokta fąla gelismistir diyemem. Yani hepsi gelismistir diyemem. Fark ettiyseniz benim de hep söylediğim rü̈gâr ve güneş enerjisi. Çünkü Türkizye'de bunlar gelisti. 
Ama diğer kaynaklarla ilgili pek bir çalıs̆ma duymadım." açıklamasını yapmışıı. Teknolojinin gelişmiş olduğunu ifade eden Fatma ise düşüncesini "Bence gelismistir. Ülkemizde gok fąla barajlar ve dağlarda yükesek yerlerde rü̈gâar tribünleri görüyoruz. Bunlarda yine bu sistemin gelistigizini gösterir." olarak ifade etmiştir.

\section{"Yenilenebilir enerji kaynak tanıtımında öğretmenin rolü” kategorisine yönelik bulgular}

Tablo 13. "Yenilenebilir Enerji Kaynak Tanttmminda Öğretmenin Rolï” Kategorisindeki Katılımc Görüşleri

\begin{tabular}{|c|c|c|c|c|c|c|c|c|c|}
\hline Kodlar & $\mathrm{f}$ & Ayşe & Fatma & Zeynep & Ali & Aylin & Asli & Veli & Hasan \\
\hline Öğrencileri bilinçlendirme & 5 & + & & & & + & + & + & + \\
\hline Rol model olma & 2 & & & + & & + & & & + \\
\hline Proje yapımını destekleme & 2 & + & & & & & + & & \\
\hline Olumlu yönleri aktarma & 2 & & + & & & & + & & \\
\hline Farkındalık kazandırma & 2 & & & + & & & & & + \\
\hline Olumlu tutum geliștirme & 2 & & & + & & & & & + \\
\hline
\end{tabular}

Tablo 13'de yenilenebilir enerji kaynaklarının tanıtımında öğretmenlerin rollerine ilişkin kodlar yer almaktadır. Beş katılımcı öğretmen rolünün öğrencileri bilinçlendirme olduğuna değinmiş ve Hasan düşüncesini șu şeklide açıklamıştır: “...Ögrretmen sadece bilgi vermekle değil, aym zamanda yönlendirmekte mükelleftir. Tüketen toplumu üreten topluma cevirmek adina ögretmenlerin ögrencilerini bilinclendirmesi gerekmektedir ayrıca." Öğretmenlerin konuya ilişskin öğrencilere rol model olması gerektiğini savunan üç katullımc1 bulunmaktadır ve bu katılımcilardan Zeynep düşüncesini "Bą̨ ögretmenlere hayrandım. Hep onlar örnek alırdim. Konusma tar:̨larndan giyim tarzlarndan bile etkilenirdim aslinda. İste bu yü̈den ögretmenler önemli. Öğgretmen ögrencisine her anlamda model olmalidır. Ögrretmenler onlara yenilenebilir enerji kaynaklarm detayl şsekilde tamitmal. Anne babadan çok öğretmen sözü dinlerler." olarak açıklamaktadır. Konuya ilişkin proje yapımını desteklemenin öğretmen rolü arasında olduğunu ifade eden iki katılımcı bulunmaktadır. Bu katılımcılardan Ayşe konuya ilişkin düşüncesini "günes enerjisi, rüzgâr enerjisi gibi enerjilerin evlerimizde bile kullanulabileceği ibtimalinin olduğunu düsünürsek, elektrik için çok daha tasarrufluğunu ögrencilere inandrap kanutlayabilirsek cok daha iyi olur. Bu da projelerle olabilir." şeklinde ifade etmiştir. Ayrıca yenilenebilir enerji kaynaklarının olumlu yönlerini aktarmanın öğretmen rolü olduğunu düşünen iki katılımcı bulunmaktadır ve Fatma düşüncesini “Öğretmenler yeni nesillere yenilenebilir enerjinin olumlu yönlerine ekonomik katkilarm yeni nesillere aktararak bu konuda daha çok önemli rol oynamaktadirlar bence." şeklinde belirtmiştir.

\section{"Yenilenebilir enerji kaynaklarına ilişkin yeni bir ders" kategorisine yönelik bulgular}

Tablo 14. "Yenilenebilir Enerji Kaynaklarnna İlişkin Yeni Bir Ders" Kategorisindeki Katıllmo Görüsleri

\begin{tabular}{lccccccccc}
\hline Kodlar & $\mathrm{f}$ & Ayșe & Fatma & Zeynep & Ali & Aylin & Aslı & Veli & Hasan \\
\hline Ders olmalı & 7 & + & + & + & + & + & + & + & \\
Ders olmamalı & 1 & & & & & & & & + \\
\hline
\end{tabular}

Yukarıda yer alan Tablo 14'de öğretmen adaylarının yenilenebilir enerji kaynaklarına ilişkin bir dersin olup olmaması gerektiğine yönelik kodları verilmiştir. Yenilenebilir enerji kaynaklarına ilişkin bir dersin olması gerektiğine değinen yedi kalıtımcı bulunmaktadır. Bu katılımcılardan Zeynep düşüncesini “üniversite çapinda bir ders olmall. Sadece bizim görevimiz değil ki bu. Herkesin farkindahk sabibi olmasi gerekmektedir. şeklinde açıklarken; ders olmaması gerektiğini belirten Hasan ise düşüncesini şu şekilde ifade etmiştir: “...bireyler daba çok kendini geliștirmeli. Bireylerin kendilerini geliştirmek, zorunda olduğu birçok konu var ve bu konularn hepsine de ayrı ayr ders açılamaz:"

"Yenilenebilir enerji kaynaklarına ilişkin verilen bilgilerin yeterlilik düzeyi” kategorisine yönelik bulgular

Tablo 15. "Yenilenebilir Enerij Kaynaklarna İliskin Verilen Bilgilerin Yeterlilik. Düzeyi” Kategorisindeki Kathlima Görüsleri

\begin{tabular}{|c|c|c|c|c|c|c|c|c|c|}
\hline Kodlar & $\mathrm{f}$ & Ayșe & Fatma & Zeynep & Ali & Aylin & Asl1 & Veli & Hasan \\
\hline Yetersiz & 7 & + & + & + & + & + & + & + & \\
\hline Yeterli & 1 & & & & & & & & + \\
\hline
\end{tabular}

Tablo 15'de öğretmen adaylarının üniversite eğitiminde verilen yenilenebilir enerji kaynaklarına ilişkin bilgilerin yeterli olup olmadığına dair düşünceleri yer almaktadır. Konuya ilişkin verilen bilgilerin yetersiz olduğunu belirten yedi katılımcı bulunmaktadır. Bu katılımcılardan Fatma düşüncesini şu şekilde açıklamıştır: “... Bununla ilgili ders dişı biç bir etkinlik bilgi aktivite yapılmad.” Zeynep ise düşüncesini “...kısa bir zaman diliminde isleniyor konu. Hįl bir sekilde ve ashinda bep teorik. Etkinlik yok aktivite yok yeterli bilgi yok." 
şeklinde ifade etmiștir. Konuya ilişkin olarak verilen bilgilerin yeterli olduğunu savunan Hasan ise düşüncesini şu şeklide ifade etmiştir: "Yeterlidir bence. Cünkü kendini yetiștirecek. Kendini geliștirecek bu nedenle verilen bilgileri kendisi detaylandracak."

“Yenilenebilir enerji kaynaklarının öğretiminde kullanılacak yöntem/teknikler” kategorisine yönelik bulgular

Tablo 16. "Yenilenebilir Enerji Kaynaklarmn Ögretiminde Kullanlacak, Yöntem/Teknikler" Kategorisindeki Katılmma Görüsleri

\begin{tabular}{|c|c|c|c|c|c|c|c|c|c|}
\hline Kodlar & $\mathrm{f}$ & Ayşe & Fatma & Zeynep & Ali & Aylin & Asli & Veli & Hasan \\
\hline Alan gezisi & 6 & & + & + & + & + & & + & + \\
\hline Projeler & 3 & & & & & + & + & & + \\
\hline Uygulamalar & 2 & + & & & + & & & & \\
\hline Zihin haritaları & 1 & & & + & & & & & \\
\hline Alt1 şapka & 1 & & & + & & & & & \\
\hline Afiş & 1 & & & + & & & & & \\
\hline Yarışma & 1 & & & + & & & & & \\
\hline Geleceğe ilişkin senaryo & 1 & & & & & + & & & \\
\hline
\end{tabular}

Tablo 16'da yenilenebilir enerji kaynaklarının öğretiminde kullanılacak yöntem/teknikler yer almaktadır. Yenilenebilir enerji kaynaklarının öğretiminde alan gezilerinin gerekliliğine inanan altı katılımc1 bulunmaktadır ve Veli düşüncesini "Gezerek gösterirdim. Cünkü bir yere giderek göstermek, ayr, anlatmak ayrndır. Gezerek göstererek yaparsak ögrencilerin daha bilinģli olacaklarm düsünüyorum. Teorikte kalmasm istemiyorum." şeklinde açıklamaktadır. Konuya ilişkin proje yapımına değinen üç katılımcı bulunmaktadır. Bu katılımcilardan Hasan “...̈̈grgencilerin yaratıcliğna bağh olarak kendilerinde farkh projelerin yapılmast gerekmektedir." şeklinde açıklama yapmıştır. Ayrıca yenilenebilir enerji kaynaklarının öğretiminde uygulamaların olması gerektiğini iki katılımcı bulunmaktadır ve Ayşe düşüncesini açıklarken "Keşke kü̈c̈̈k panellerle bu enerjilleri bį. gösterebilsek. Mesela böylece ögrencilerinde panellerle ilgili bilgilerin uygulamal olarak görülmesi daba etkili ögrenme olacaktır." ifadesini kullanmıştır. Bununla birlikte yenilenebilir enerji kaynaklarının zihin haritaları, altı şapka, afiş ve yarışmalarla öğretilmesi gerektiğini belirten öğretmen adayı Zeynep, düşüncesini şu şekilde

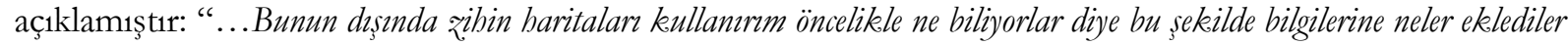
diye teyit ederim. Altt şapkali dïssïnme eğlenceli aktivite olacaktrr. Aslinda kalic ögrenmede sağlamıs olurum. Son olarak bu bilgilerin başkealarna ulașmasım sağlarm. Bunu da afişlerle posterlerle sağlarm. Kendileri tasarlarlar bir afişi grup olarak. Yarıșma uzun soluklu. Sonucunda da belki bir ağac fidesi hediye ederim daba çevreci olmalarm sağlayabilirim." Geleceğe ilişkin senaryolar ile bu kaynakların öğretilebileceğini savunan öğretmen adayı Aylin'dir. Aylin düşüncesini "Eğer gelecekte oluşabilecek senaryolardan babsedebilirdim. Kaynaklarn önemini çok faə̧la tüketmeden artık bu konuda bilinç kaz̧anmayn enerjiye dönüsțïrmeyi babsederdim..." şeklinde açılamıştır.

"Yenilenebilir enerji kaynaklarının geliştirdiği okuryazarlık türleri” kategorisine yönelik bulgular

Tablo 17. "Yenilenebilir Enerji Kaynaklarn Gelistirdiği Okuryazarllk. Türleri” Kategorisindeki Katılmmc Görüsleri

\begin{tabular}{|c|c|c|c|c|c|c|c|c|c|}
\hline Kodlar & $\mathrm{f}$ & Ayşe & Fatma & Zeynep & Ali & Aylin & Asl1 & Veli & Hasan \\
\hline Çevre okuryazarlığ1 & 7 & + & + & + & + & & + & + & + \\
\hline Fen okuryazarlığ1 & 4 & + & + & & & + & + & & \\
\hline Teknoloji okuryazarllğ1 & 2 & + & & + & & & & & \\
\hline Medya okuryazarlığı & 1 & & & + & & & & & \\
\hline İnternet okuryazarlığ1 & 1 & & & + & & & & & \\
\hline
\end{tabular}

Tablo 17'de öğretmen adaylarına göre yenilenebilir enerji kaynaklarının geliştirdiği okuryazarlık türleri yer almaktadır. Konuya ilişkin çevre okuryazarlığına değinen yedi kattlımcı bulunmaktadır. Bu katıllmmc1lardan Hasan ise düşüncelerini "Cevre okuryazarlgğm gelistirir bence. Çünkü zaten çevreyle ilgili tüm konular kapsar. Cevreye duyarl bireyler yetismesi açısindan hocam. Cevreye ne kadar duyarl olursak çevre okuryazarlğımı da gelisecektir." olarak ifade etmiştir. Yenilenebilir enerji kaynaklarının fen okuryazarlığı ile ilişkisinin olduğunu belirten dört katılımcı bulunmaktadır. Ayşe ise düşüncesini şu şekilde belirtmiştir: "...fen okuryazarly̆g olabilir. Cünkü bu konu fendir. Fen ile ilgili olan seyler fen okuryazarliğm etkiler." ifadesini kullanmıştır. Bunun yanı sıra Zeynep, yenilenebilir enerji kaynaklarının medya okuryazarlığı ve internet okuryazarllğı ile ilgisi olduğunu düşünmekte ve düşüncesini şu şeklide belirtmektedir: "...Ş̧imdiki çocuklar internet odakl yassyyor. Yenilenebilir enerji kaynaklar kapsaminda ders için hažrllklarm eminim de internetten yapacaklardr. Medya zaten çok güncel ve popüler. Bu nedenle internet okuryazarlğgn ve medya okuryazarluğm bile gelistivebilir...” 


\section{"Yenilenebilir enerji kaynaklarına ilişkin öneriler" kategorisine yönelik bulgular}

Tablo 18. "Yenilenebilir Enerji Kaynaklarna İliskin Öneriler" Kategorisindeki Katılımı Görüsleri

\begin{tabular}{|c|c|c|c|c|c|c|c|c|c|}
\hline Kodlar & $\mathrm{f}$ & Ayşe & Fatma & Zeynep & Ali & Aylin & Asli & Veli & Hasan \\
\hline Bilinçlendirme çalışmaları & 5 & & + & + & + & + & + & & \\
\hline Uygulamalı ders & 2 & + & & + & & & & & \\
\hline Çizgi film tasarımı & 2 & & & + & + & & & & \\
\hline Beyin göçünü engelleme & 1 & & & & & & & + & \\
\hline Reklamlarla tanıtım yapma & 1 & & & & & & & & + \\
\hline Tasarım yarışmaları düzenleme & 1 & & & & & & & & + \\
\hline Nitelikli insan yetiştirme çalışmaları & 1 & & & & & & & & + \\
\hline
\end{tabular}

Yukarıda yer alan Tablo 18 incelendiğinde, öğretmen adaylarının yenilenebilir enerji kaynaklarına yönelik yapılması gerekenlere ilişkin önerileri yer almaktadır. Yenilenebilir enerji kaynaklarına ilişkin bilinçlendirme çalışmalarının yapılması gerektiğini ifade eden beş katılımcı bulunmaktadır ve Fatma düşüncesini "Ĕ̈gr insanlar bilinçlendirilirse enerji kaynaklar daha doğru şekilde kullanulr... Bunun içinde bence alannda uæman kişilerin okullara gelip konferans vermeleri gerekir..." şeklinde ifade etmiştir. Bilinçlendirme çalışmalarının sosyal medya ile gerçekleştirilebileceğini ifade eden öğretmen adayı Aslı ise düşüncesini "...son zamanlarda herkes sosyal medya kullanyor. Bu açıdan sosyal medyada çok farkel etkinlikle, tanutum, haberler eklenirse fark edileceğini düş̈̈nüyorum...” şeklinde açıklamışır. Ayşe ve Zeynep uygulamalı derslerin olmasına yönelik öneri vermiş ve Ayşe düşüncesini “... detaylh bir ders almak, yani uygulamaya geçmek daba önemli. Bizde bunlar ögretmeye yatkin ögretmenler olacağımı içinde yaparak yaşayarak çok daba iyi olacağın düsü̈nüyorum." şeklinde belirtmiştir. Çizgi filmler üzerine öneri veren iki katılımcı bulunmaktadır ve Ali düşüncesini“....mesela birlikte doğa sevgisi enerji kaynaklarmm kullanmı, bunlarda gösterilebilir mesela. Bilinçaltnna yerleştirme öyle diveyim. Cįzgi filmlerle." olarak ifade etmiştir. Beyin göçünün engellenmesini belirten öğretmen adayı Veli'dir ve Veli düşüncesini "Günümüzde hocam fazlasıyla beyin göçü veriyoruz bi‡. Bu beyin göçünün önüne geçilmesi lazım. Böylelikle

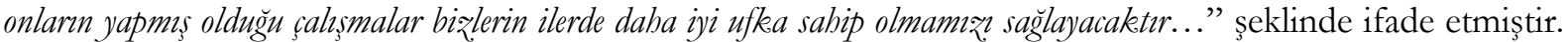
Yenilenebilir enerji kaynaklarına yönelik reklamların, tasarım yarışmalarının ve nitelikli insan yetiştirilmesine yönelik öneriler veren Hasan düşüncesini "Mesela jeotermal enerjimiz var. Ama Akdeniz bölgesi gibi ilgi çekmiyor. Kaphcalarn reklamlar yapulmalıdır. Farkindahk sağlamak adina ögretim kademelerine uygun olarak tasarm yarrșmalar yapılabilir. Ödül olarak da kaphca tatili verilebilir."

\section{Tartışma, Sonuç ve Öneriler}

\section{“Yenilenebilir Enerji Kaynakları Tanım” Kategorisine Yönelik Tartışma ve Sonuç}

Fen bilgisi öğretmen adaylarının yenilenebilir enerji kaynakları tanımları incelendiğinde, bu kaynakları sürekliliği devam eden kaynak, sonsuz üretim, çevre dostu, kendini yenileyen kaynaklar olarak tanımladıkları sonucuna ulaşılmıştır. Bozdoğan ve Yiğit (2014, s. 118) tarafindan yapılan çalışmada, katılımcıların yenilenebilir enerji kaynaklarını, kendini yenileyen enerji, sonsuz, sürekli var olan enerji olarak tanımladıklarını belirtilmiştir. Öğretmen adayları konuya ilişkin tanım yaparken, güneş, rüzgâr gibi kavramların dünya üzerinde tükenme riski olmadığı düşünerek, yenilenebilir enerji kaynaklarını sonsuz, sürekli var olan enerji olarak düşünmüss olabilirler. Alanyazında yenilenebilir enerji kaynaklarının temiz, çevre dostu kaynaklar olarak nitelendiren başka çalışmaların olduğu belirlenmiştir (Ataman, 2007, s.9; Kumbur, Özer, Özsoy ve Avc1, 2005, s. 20; Varinca ve Gönüllü, 2006, s. 270; Whitman, 2013, s. 2). Dolayısıyla çalışmadan elde edilen bu sonuçlar alanyazınla benzerlik göstermektedir. Öğretmen adaylarının bazıları ise yenilenebilir enerji kaynaklarını, doğa olayların faydaya çevirme ve tüketilen kaynakları doğaya kavuşturma olarak tanımlamışlardır. Ayrıca öğretmen adayları yenilenebilir enerji kaynaklarını göz önüne aldıklarında, bu kaynakların doğal bir süreç içerisinde, döngü halinde enerji elde edilmesine bağlı olarak düşünmelerinden dolayı, tekrar kullanılabilen kaynaklar olarak tanımlamıss olabilirler.

\section{“Yenilenebilir Enerji Kaynakları Örnekler” Kategorisine Yönelik Tartışma ve Sonuç}

Fen bilgisi öğretmen adaylarının yenilenebilir enerji kaynaklarına verdikleri örnekler incelendiğinde, öğretmen adayların rüzgâr, güneş, hidrolik, jeotermal, hidrojen, gelgit, ses enerjisini verdikleri sonucuna ulaşılmışıır. Çelikler ve Kara (2011, s. 536) iklim şartları, konumu ve zengin potansiyelinden dolayı Türkiye'nin yenilenebilir enerji kaynakları bakımından önemli bir yere sahip olduğunu belirtmektedir. Fen bilgisi öğretmen adaylarının da konuya ilişkin olarak önekler vermesi alanyazını desteklemektedir. Alanyazın incelendiğinde rüzgâr, jeotermal, hidrojen, biyokütle, güneş, hidrolik ve dalga enerjisinin yenilenebilir enerji kaynakları olduğuna ilişkin çalışmalar yer almaktadır (Liarakou, Gavrilakis ve Flouri, 2008, s. 120). Dolayısıyla çalışmadan elde edilen örnekler, alanyazın sonucuyla örtüşmektedir. Ayrıca 
öğretmen adaylarının daha çok güneş ve rüzgâr enerjisini değindikleri sonucuna ulaşılmıştır. Alanyazında ise bu sonucu destekler nitelikte çalışmaların yer aldığı belirlenmiştir (Töman ve Odabaşı Çimen, 2013, s. 59). Öğretmen adaylarının konuya ilişkin olarak daha çok güneş ve rüzgâr enerjisini örnek olarak vermesi, bu enerji türleri ile günlük yaşamda daha sık karşılaşılmasından kaynaklı olarak ortaya çıkmış olabilir. Ayrıca katılımcıların biyokütle ve gelgit enerjisini örnek olarak daha az tercih ettikleri sonucuna ulaşılmıştır. Elde edilen bu sonuç öğretmen adaylarının biyokütle, gelgit ve hidroelektrik enerjisini çok fazla bilmedikleri için örnekleyemedikleri (Karakaya Cirıt, 2017, s. 28) sonucuyla benzerlik göstermektedir. Katılımcılardan biri yenilenebilir enerji kaynaklarına örnek olarak ses enerjisini vermiştir. Bu durumun ortaya çıkma sebebi öğretmen adayının konuya ilişkin eksik bilgilere sahip olmasından kaynaklanmış olabilir. Saraç ve Bedir (2014, s. 33) çalışmasında öğretmen adaylarının yenilenebilir enerji kaynaklarına yönelik bilgi eksikliğinin olduğu ifadesi ile edilen bu sonuç benzerlik göstermektedir.

\section{"Yenilenebilir Enerji Kaynaklarına Yönelik Algılar” Kategorisine Yönelik Tartışma ve Sonuç}

Öğretmen adayları yenilenebilir enerji kaynaklarına yönelik yeterli algyya sahip olmadıklarını belirtmişlerdir. Öğretmen adaylarının konuya ilişkin olarak yeterli bilgi sahibi olmadığını belirten çalışmalar alanyazında yer almaktadır (Çelikler ve Kara, 2011, s. 25; Lay, Kho, Treasgust ve Chandrasegan, 2012, s. 200). Öğretmen adaylarının bu durumu meraklı birey azlığı, araştırmamayı sevmeme, eğitim eksikliği, okuma eksikliği gibi durumlara bağladıkları belirlenmiştir. Akçöltekin ve Doğan (2013, s. 151-152) çalışmasında yenilenebilir enerji kaynaklarının öğretilmesi için bireylere iyi bir eğitim verilmesi gerektiğini ifade etmektedirler. Öğretmen adaylarının konuya ilişkin olarak eğitim eksikliğine değinme nedeni, eğitim hayatları boyunca, yenilenebilir enerji kaynaklarına yönelik yeterli bilgi seviyesine ulaşamadıklarını düşünmeleri sonucu ortaya çıkmış olabilir. Dolayısıyla bireylerin bu konuda yerli algiya sahip olamamaları, öğretmen adaylarının bireylerin yerine kendilerini koymalarından kaynaklanmış olabilir. Ayrıca öğretmen adayları çevrelerinde, akran ve ailelerinde okumaya yönelik alışkanlığın olmaması nedeniyle, bireylerin bu konu hakkından yeterli bir algıya sahip olamayacaklarını düşünmüş olabilirler. Fen bilgisi öğretmen adaylarının biri ise konuya ilişkin algıların yeterli düzeyde olduğunu belirtmiştir. Ertaş, Şen ve Parmasızoğlu (2011, s.195) çalışmasında öğrencilerin yenilenebilir enerji kaynaklarını günlük hayatla ilişkilendirdiklerini belirtmiştir. Dolayısıyla öğretmen adayı yenilenebilir enerji kaynaklarının günlük yaşamda sürekli kullanılan bir kaynak olduğunu düşünmesinden dolayı, bireylerin konuya ilişkin yeterli algyya sahip olduğunu ifade etmiş olabilir.

\section{“En Kullanı̧̧ı Yenilenebilir Enerji Kaynakları” Kategorisine Yönelik Tartışma ve Sonuç}

Katılımcılar güneş ve rüzgâr enerjisini Türkiye için en kullanışlı yenilenebilir enerji kaynakları olarak düşünmüşlerdir. Ağaçbiçer (2010, s.120) tarafindan yapılan çalısmada, Türkiye'nin coğrafik yapısı göz önünde bulundurulduğunda, ülkemiz için güneş enerjisinin kullanışlı olduğu ifade edilmektedir. Çalışmanın bir diğer sonucu ise Türkiye için en kullanışlı yenilenebilir enerji kaynakları arasında hidroelektrik, jeotermal ve gelgit enerjisi olduğudur. Bıyıklı (2018, s.7) gerçekleştirdiği çalışmasında, Türkiye'nin jeotermal açıdan dünyada yedinci sırada olduğunu, bu nedenle jeotermal zenginliğin Türkiye için kullanışlı bir enerji olduğunu ifade etmiştir. Dolayısıyla elde edilen sonuç alanyazınla benzerlik göstermektedir. Fen bilgisi öğretmen adaylarının "kaplıca" olarak adlandırılan tesislerin jeotermal enerji kapsamında ortaya çıkarak kurulduğunu ve bu tesislerin yaygın bir şekilde ülkemizde yer aldığını düşünmelerinden dolayı, bu sonucun ortaya çıktığı söylenebilir. Bodur ve Şenyuva (2013, s. 38) tarafindan yapılan çalışmada, üniversite ögrencilerinin hidroelektrik enerjisinin Türkiye için önemli olduğunu ve bu nedenle santrallerin kurulmas1 gerektiğini ifade ettiklerini belirtmektedir. Dolayısıyla elde edilen bu sonuçla alanyazının desteklendiği görülmektedir. Katılımcıların bu kayaklar arasında biyokütle enerjisini ifade etmedikleri sonucuna ulaşılmıştır. Kaldellis, Kapsali ve Katsanou (2012, s. 38) biyokütle enerjisinin bireyler tarafindan diğer enerji türlerine göre oldukça az bilindiği ifade edilmiştir. Bu durum öğretmen adaylarının derslerde ve çevrelerinde biyokütleye ilişkin yeterli somut örnekleri görmemelerinden kaynaklanmış olabilir.

\section{“En Yaygın Kullanılan Yenilenebilir Enerji Kaynakları” Kategorisine Yönelik Tartışma ve Sonuç}

Türkiye'de en yaygın olarak kullanılan yenilenebilir enerji kaynaklarının rüzgâr, güneş, hidroelektrik ve jeotermal enerji olduğu sonucuna ulaşılmıştır. Bıyıklı (2018, s. 7) çalışmasında, Akdeniz bölgesinde genel olarak rüzgâr ve güneş enerjisinin kullanıldığını ifade etmiştir. Bu çalışmanın yapıldığı üniversitenin Akdeniz bölgesinde yer alması ve bu bölgenin de sözü edilen enerji kaynakları bakımında zengin olması, yaşamlarında bu kaynaklardan elde edilen enerjileri kullanmaları nedeniyle, bu sonuçlar ortaya çıkmış olabilir. Özellikle araştırmanın yapıldığı bölgede, hemen hemen tüm evlerin çatılarında güneş enerjisi yer 
almakta, şehrin konumu gereği iller arası seyahatler sırasında rüzgârgüllerinin varlığı kolaylıkla görülmekte, katılımcılar bahsi geçen şehirde barajın olduğunu bilmekte ve jeotermal enerjinin kullanıldığı kaplıcaya ait reklamlar yapıldığını görmektedirler. Bu durumdan dolayı, öğretmen adayları Türkiye'de en yaygın olarak kullanılan enerji kaynaklarını rüzgâr, güneş, hidroelektrik ve jeotermal enerji olarak sıralamış olabilirler. Çalışmanın diğer sonuçları incelendiğinde, katılımcıların en yaygın enerji kaynakları arasında biyokütle, gelgit eneriisini örnek olarak vermedikleri görülmektedir. Karytsas ve Theodoropoulou (2014, s. 484) çalışmasında bireylerin biyokütle enerjisinden fazla haberdar olmadığı, Bıyıklı (2018, s. 9) ise gelgit enerjisinin, rüzgâr ve güneş enerjisine göre nispeten daha yeni olmasından dolayı, bilinmediğini ifade edilmektedir. Bu durumun ortaya çıkma nedeni öğretmen adaylarının konuya ilişkin olarak yapılan çalışmaların yeterli düzeyde kamuoyuna sunulmadığını düşünmelerinden kaynaklanmış olabilir.

\section{"Yenilenebilir Enerji Kaynaklarına İlişkin Etkinliğe Katılım” Kategorisine Yönelik Tartışma ve Sonuç}

Bazı katılımcıların yenilenebilir enerji kaynaklarına yönelik gerçekleştirilen etkinliğe katıldıkları sonucuna ulaşılmıştır. Alanyazında okul dışı etkinliklerinin kalıcı öğrenmede etkili olduğunu belirten çalışmalar yer almaktadır (Bozdoğan ve Yalçın, 2006, s. 109; Okur Berberoğlu ve Uygun, 2013, s. 32). Balkan Kıyıcı ve Atabek Yiğit (2010, s. 237) çalışmasında, öğretmen adaylarının rüzgâr tribünlerine götürülmesinden sonra, bu kaynağa yönelik olarak anlamlı öğrenmelerin sağlandığını belirtmiştir. Bireylerin yenilenebilir enerji kaynakları konusunda yeterli bilgi düzeyine sahip olduğunu belirten bir öğretmen aday1 rüzgâr tribünlerine etkinlik olarak gittiğini ifade etmiştir. Dolayısıyla öğretmen adayı alan gezisi ile bu kaynağı somut olarak gördügü için bilgilerinin kalıcı hale gelmesinden dolayı, konuya ilişkin yeterli bilgi düzeyine sahip olunduğunu belirtmiş olabilir. Hurley (2006, s. 64) çalışmasında alan gezilerinin deneyimle birlikte bilgileri pekiştirdiğini ifade etmiştir. Dolayısıyla öğretmen adaylarının alan gezilerine katılmamaları, konuya ilişkin yetersiz düzeyde bilgi sahibi olduklarını ifade etmelerine de neden olmuş olabilir.

\section{“Yenilenebilir Enerji Kaynaklarının İşlevi” Kategorisine Yönelik Tartışma ve Sonuç}

Öğretmen adaylarının yenilenebilir enerji kaynaklarının işlevi adı altında, artan nüfus gereksinimini karşılama, doğanın korunması, yaşamı kolaylaştırma, sağlıklı enerji üretimi ve enerji dönüşümü kavramlarına değindikleri sonucuna ulaşılmıştır. Artan nüfusun gereksinimleri doğrultusunda ihtiyaç duyulan enerjilerin yenilenebilir enerjiler ile sağlandığını belirten (Koroneos, Spachos ve Moussiopoulos, 2003, s. 296; Sathaye ve diğerleri, 2011, s. 18; Saatçioğlu ve Küçükaksoy, 2004, s. 20), yenilenebilir enerji kaynaklarının temiz bir çevreye sahip olunması açısından önemli olduğuna vurgu yapan (Bayraç, 2010, s. 248; Bozdoğan ve Yiğit, 2014, s. 118) bazı çalışmaların alanyazında yer aldığı belirlenmiştir. Elde edilen bu sonuçların alanyazınla örtüştüğü söylenebilir. Turan (2006, s. 17) çalışmasında yenilenebilir enerji kaynaklarının geri dönüşümü mümkün olan enerji kaynakları olduğunu belirtmiştir. Öğretmen adayları da bu kaynakların geri dönüşümlerle elde edildiğini düşünerek, enerji dönüşümü kavramını yenilenebilir enerji kaynaklarının işlevi olarak belirtmiş olabilirler. Ayrıca yenilenebilir enerji kaynaklarının sürdürülebilir yaşam kavramına vurgu yaptığı ve bu doğrultuda insan yaşamını kolaylaştırdığına yönelik çalışmalar bulunmaktadır (Bang vd, 2000, s. 451; Upreti, 2004, s. 786). Ayrica Sathaye ve diğerleri (2011, s. 19) tarafından gerçekleştirilen çalışmada, yenilenebilir enerji kaynaklarının bireylerin yaşamlarındaki kaliteyi arttırdığ1 belirtilmiştir. Çalışmanın yapıldığı şehirde olan Kahramanmaraş’ta özellikle rüzgâr, güneş, jeotermal ve hidroelektrik kaynaklarının olması ve bu bölgede mevcut kaynakların sıklıkla kullanılmasindan dolayı, öğretmen adayları yenilenebilir enerji kaynaklarının işlevlerinden birini yaşamı kolaylaştırma olarak düşünmüş olabilirler.

\section{"Yenilenebilir Enerji Kaynaklarının Olumlu Yönleri” Kategorisine Yönelik Tartı̧̧ma ve Sonuç}

Öğretmen adaylarının daha çok yenilenebilir enerji kaynaklarının ekonomikliğine vurgu yaptıkları sonucuna ulaşılmıştır. Elde edilen bu sonuç ile yenilenebilir enerji kaynaklarının ekonomikliğine ilişkin bilgi veren çalışmalar (Gençoğlu, 2012, s. 6; Karakaya Cırı1, 2017, s. 34) benzerlik göstermektedir. Elde edilen başka bir sonuç ise yenilenebilir enerji kaynaklarının dış ülkelere bağımlı olmamayı sağlamasıdır. Alanyazın incelendiğinde yenilenebilir enerji kaynaklarının dış ülkelere olan bağlllı̆̆ azalttığını belirten çalışmaların olduğu tespit edilmiştir (Bozkurt, 2008, s. 63; Saraç ve Bedir, 2014, s. 37). Ayrıca bu çalışmada yenilenebilir enerji kaynaklarının kırsal alanlara destek olduğu sonucuna ulaşılmıştır. Elde edilen bu sonuç Bayraç (2010) tarafından yapılan çalışmada, kırsal bölgelerin kalkınmasında, yenilenebilir enerji kaynaklarının önemli bir etkisi olduğu ifadesiyle örtüşmektedir. Öğretmen adayları yenilenebilir enerji kaynaklarının olumu yönlerini ifade ederken, temiz kaynak ve atık üretmeme gibi kavramlara değinmeleri, çalışmanın diğer sonuçları arasında yer almaktadır. Gençoğlu (2012, s. 1) çalışmasında, yenilenebilir enerji kaynaklarının insan ve 
çevreye herhangi bir tehdit oluşturmadığını, Varınca ve Gönüllü (2006, s. 271) ise yenilenebilir enerji kaynaklarının, fosil kaynaklar gibi doğaya olumsuz bir etki vermemesinden dolayı, yenilenebilir enerji kaynaklarının temiz bir enerji kaynağı olduğunu ifade etmiştir. Dolayısıyla yenilenebilir enerji kaynaklarının temiz ve atık üretmeyen kaynak olduğu sonucu, alanyazınla benzerlik gösterdiği söylenebilir.

\section{“Yenilenebilir Enerji Kaynaklarının Olumsuz Yönleri” Kategorisine Yönelik Tartışma ve Sonuç}

Katılımclara göre enerji kaynaklarının kurulumunda, tarım arazileri işgal edilmektedir. Cebesoy ve Karışın (2017, s. 1395) öğretmen adaylarının bu kaynaklarının kurumunda tarım arazilerinin yok edildiğini, bu durumunda bir dezavantaj olduğunu ifade etmiştir. Elde edilen bu sonucun alanyazınla benzerlik gösterdiği görülmektedir. Fakat alanyazında özellikle rüzgâr santrallerinin kurulum aşamasında arazinin yapısına olumsuz bir etki göstermediğini, arazilerin çevresinin hayvancılık ve tarımda kullanılabileceğine ilişkin araştırmalar yer almaktadır (Ağaçbiçer, 2010, s. 124). Dolayısıyla elde edilen bu sonucun alanyazınla benzerlik göstermediği söylenebilir. Bu durumun ortaya çıkması, öğretmen adaylarının baraj yapımını, kaplıcaların kurulumunu göz önüne aldıklarında, arazilerinin işgal edilmesiyle, o bölgede tarımsal faaliyetlerin yok olacağını düşünmelerinden kaynaklanmış olabilir. Çalışmadan elde edilen başka bir sonuç ise yenilenebilir enerji kaynaklarının canlılara zarar vermesidir. Elde edilen bu sonuç Ağaçbiçer'in (2010, s. 68) rüzgâr tribünlerinin kuşların ölümüne ve göç yollarının değiştirmelerine neden olduğu ifadesiyle örtüşmektedir. Öğretmen adayları yenilenebilir enerji kaynaklarından rüzgâr enerjisini göz önüne alarak, bu kaynağın canlılara zarar verdiğini belirtirmiş olabilirler. Ayrıca öğretmen adayları ağaç kesme işlemleri sonucunda bu kaynakların kurulumunun gerçekleştiğini, barajların iklime olumsuz etkilerini göz önüne alarak, barajların çevresinde yaşamını sürdüren canlıların, kötü yönde etkileneceğini düşünmelerinden dolayı, bu sonucun ortaya çıktığı söylenebilir. Katılımcıların bazıları yenilenebilir enerji kaynaklarının bazı aylarda verimlerinin düştüğuñü belirtmiştir. Bu durumun ortaya çıkması, öğretmen adaylarının özellikle yaz aylarında rüzgârın kesintili olmasından dolayı, bu enerjinin sürekli olarak kullanılmayacağını düşünmelerinden ortaya çıkmış olabilir. Öğretmen adayları biyokütle enerjisini yenilenebilir enerji kaynağına ilişskin örnek olarak vermelerine rağmen Türkiye için kullanışlı ve yaygın enerji kaynakları arasında biyokütle enerjisine değinmemişlerdir. Kumbur ve diğerleri (2005, s. 20) tarafindan yapılan çalışmada, biyokütle enerjisinin ortaya çıkması sırasında karbondioksit gazının ortaya çıktığını ve bu durumunda yenilenebilir enerji kaynaklarının bir dezavantajı olduğunu belirtmiştir. Dolayısıyla öğretmen adayları biyokütle enerjisinin Türkiye'de kullanımının olmadığını düşünerek, bu enerjiye dayalı olarak olumsuz etkileri belirtmemiş olabilirler.

\section{“Yenilenebilir Enerji Kaynaklarının Ülkeye Katkıları” Kategorisine Yönelik Tartışma ve Sonuç}

Fen bilgisi öğretmen adayları yenilenebilir enerji kaynaklarının ülkeye ekonomik katkı sağladıklarını belirtmişlerdir. Bu sonuç Zeray'ın (2010, s. 104) çalışmada yenilenebilir enerji kaynaklarının ekonomik olması sonucuyla örtüşmektedir. Bu durum katılımcıların yenilenemez enerji kaynaklarını tükenmeyen kaynak olarak bilmeleri ve bu doğrultuda tüketimi azalttı̆̆ için ekonomiyi koruduğunu düşünmelerinden kaynaklanmış olabilir. Elde edilen bir başka sonuç ise dış ülkelere olan bağımlılığın azalmasıdır. Bozkurt (2008, s. 63) çalışmasında yenilenebilir enerji kaynaklarının elde edilmesi dış ülkelerden bağımsızlı̆̆ sağlamaktadır ifadesiyle örtüşmektedir. Bu durum ise öğretmen adaylarının sürekli medyada dış ülkeler ile doğal gaz ve petrol krizinin yaşanmasını göz önüne aldıkları için ortaya çıkmış olabilir. Ayrıca çalışmadan elde edilen başka bir sonuç ise yenilenebilir enerji kaynaklarının ülkenin refah düzeyini artırmasıdır. Açıkgöz (2011, s.610) ise yenilenebilir enerji kaynaklarının bireylerin, toplumun yaşam kalitesini sağladığını ve bu doğrultuda refah düzeyinin arttı̆ğı belirtmektedir. Katılımcılar Türkiye'nin zengin alt yap1 ve kaynaklara sahip olması ve bunların diş ülkelere pazarlanmasıyla ülkenin refah düzeyinin artacağını düşünmüş olabilirler. Ayrıca katılımcıların bazıları bu kaynakların turist çekeceğini belirtmişlerdir. Bıyıklı (2018, s.8) Türkiye'nin jeotermal açıdan dünya genelinde üst sıralarda olduğunu ifade etmiştir. Katıllımcılar kaplıca, ılıca gibi merkezlerin Türkiye'de yoğun bir şekilde bulunmasından dolayı bu enerji kaynağının turist çekebileceğini düşünmüş olabilirler.

\section{"Yenilenebilir Enerji Kaynaklarını Kullanan Teknolojinin Gelişmişliği” Kategorisine Yönelik Tartı̧̧ma ve Sonuç}

Katılımcıların çoğunluğu bu teknolojinin gelişmemiş olduğunu belirtmişlerdir. Bu gelişmemişliği ise öğretmen adaylarının dışa göçe, bilgilendirme eksikliğine ve bilim insanlarının yeterli bilgi düzeyine sahip olmamalarına bağladıkları sonucuna ulaşılmıştır. Gupta (2003, s. 165) çalışmasında donanımlı bireylerin azlığı nedeniyle yenilenebilir enerji kaynak teknolojisinin sınırlı kaldığını; Danijela, Popovski, Gecevska, 
Vasilevska ve Tesic (2011, s. 3190) yenilenebilir enerji kaynaklarına yönelik teknolojinin gelişebilmesi için iyi eğitim almış bireylere ihtiyacın olduğunu ifade etmektedir. Dolayısıyla öğretmen adayları yenilenemez enerji kaynaklarının günümüzde daha fazla kullanıldığını düşünerek, yenilenebilir enerji kaynak teknolojisinin gelişmediğini düşünmüş olabilirler. Bir katılımcı bu teknolojinin geliştiğini ifade etmiş ve bu gelişmişliği barajlar ve rüzgâr tribünlerinin varlığına bağlamıştır. Karytsas and Theodoropoulou (2014, s. 484) çalışmasında genel anlamda bireylerin dalga ve gelgit enerjisi hakkında çok fazla bilgi sahibi olmadıklarını belirtmiştir. Dolayısıyla öğretmen adayının yenilenebilir enerji kaynaklarından baraj ve rüzgâr enerjisini düşünerek bu sonuca vardığ1 söylenebilir.

\section{"Yenilenebilir Enerji Kaynak Tanıtımında Öğretmenin Rolü” Kategorisine Yönelik Tartışma ve Sonuç}

Fen bilgisi öğretmen adayları yenilenebilir enerji kaynaklarının tanıtımında öğretmenlerin bireyleri bilinçlendirmesi gerektiğini, rol model olduğunu, proje yapımı destek vermesi gerektiğini, farkındalık ve olumlu tutum geliştirmelerini sağlama gibi rollere sahip olması gerektiğini ifade etmişlerdir. Alanyazında ise bu sonuçları destekler nitelikte çalışmalar yer almaktadır. Saraç ve Bedir (2014, s. 30) bireylerin yenilenebilir enerji kaynaklarına yönelik bilinçlendirilmesi gerektiğini, Halder, Havu-Nuutinn, Pietarinen ve Polkenon (2011, s. 1234) öğretmenlerin yenilenebilir enerji kaynaklarına ilişkin tutumlarının ve farkındalıklarının üst düzeyde olması gerektiğini, Çelikten, Şanal ve Yeni (2006, s. 215) öğretmenlerin öğrencilerine her konuda rol model olması gerektiğini ifade etmiştir. Dolayısıyla öğretmen adayları ögrretmenlerin genel özelliklerini göz önüne alarak her konuda öğretmenlerin farkındalık ve tutum gibi duyuşsal özellikleri kazandırması, rol model olmasını düşünerek bu sonucun ortaya çıkmasına neden olmuş olabilirler.

\section{"Yenilenebilir Enerji Kaynaklarına İlişkin Yeni Bir Ders" Kategorisine Yönelik Tartışma ve Sonuç}

Öğretmen adaylarının çoğu yenilenebilir enerji kaynaklanına ilişkin olarak teknoloji ile ilişkili ve üniversite kapsamında bir ders olması gerektiğini, bireylerin donanımlı birey olarak yetişmesi gerektiğini belirtmişlerdir. Bhattacharya (2001, s. 95) tarafından gerçekleştirilen çalışmada da üniversitelerin özellikle bireylerin yenilenebilir enerji eğitimine yönelik önemli bir işleve sahip olduğunu belirtmiştir. Elder (2003, s. 78) bireylerin doğal sistemler ve çevre arasındaki ilişkiyi kavramları gerektiğini ifade ederken ayrıca bireylerin doğal sistem ilişkilerini günlük yaşamlarına aktarabilmeleri gerektiğini ifade etmiştir. $\mathrm{Bu}$ çalışmada Marcinkowsky (1991) tarafindan yapılan çalışma referans alındığı için, tüm insanların çevre okuryazarı olması gerektiği düşünülmektedir. Dolayısıyla öğretmen adayları da çevre kapsamında yer alan bir kavram olan yenilenebilir enerji kaynaklarının bütün bireylerin bilmesi gerektiğini ve bu eğitimin ancak üniversite düzeyinde verilebileceğini düşünmelerinden kaynaklı olarak ortaya çıkmış olabilir. Ayrıca Danijela ve diğerleri (2011, s. 3191) tarafından yapılan çalışmada yenilenebilir enerji kaynaklarına ilişkin donanımlı bireylerin olması gerektiğini belirtmektedir. Dolayısıyla çalışmanın sonuçları ile alanyazının örtüştüğü ifade edilebilir.

\section{"Yenilenebilir Enerji Kaynaklarına İlişkin Verilen Bilgilerin Yeterlilik Düzeyi" Kategorisine Yönelik Tartışma ve Sonuç}

Fen bilgisi öğretmen adaylarının çoğu yenilenebilir enerji kaynaklarına ilişkin verilen bilgilerin yeterli düzeyde olmadığını düşünmektedirler. "Yenilenebilir enerji kaynaklarına ilişkin yeni bir ders" kategorisine yönelik tartışma sonuçta görüldüğü üzere öğretmen adaylarının yenilenebilir enerji kaynaklarına yönelik yeni bir ders açılması gerektiği belirtmişlerdir. Dolayısıyla öğretmen adayları yenilenebilir enerji kaynaklarına ilişkin verilen bilgilerin yetersiz olduğunu düşündükleri için, konuya ilişkin olarak bir dersin açılmasının gerekli olduğunu ifade etmiş olabilirler. Tanrıverdi (2009, s. 89) tarafından yapılan çalışmada, yenilenebilir enerji kaynaklarına ilişkin öğrencilere verilen bilgilerin yetersiz olduğu belirtilmiştir. Alanyazında fen bilimlerinin içeriği göz önüne alındığında, yenilenebilir enerji kaynaklarına ilişkin verilen bilgilerin yetersizliklerine değinen başka çalışmalarında olduğu tespit edilmiştir (Aktamış, 2011, s.246; Lay, Khoo, Treagust ve Chandrasegan, 2012, s. 200). Çalışmanın sonucuyla alanyazındaki çalışmaların paralellik gösterdiği söylenebilir. 


\section{"Yenilenebilir Enerji Kaynaklarının Öğretiminde Kullanılacak Yöntem/Teknikler" Kategorisine Yönelik Tartışma ve Sonuç}

Yenilenebilir enerji kaynaklarının öğretiminde kullanılacak yöntem/teknikler kategorisi incelendiğinde, öğretmen adaylarının daha çok yapılandırmacı yaklaşım içinde yer alan etkinliklere yer verdikleri sonucuna ulaşılmıştır. Perkins (1999, s. 7), yapılandırmacı yaklaşımdaki aktivitelerin bilginin kalıclık düzeyine etkisini vurgulamıştır. Dolayısyla elde edilen sonucun alanyazınla benzerlik gösterdiği söylenebilir. Katılımların konuya ilişkin alan gezilerinin daha çok etkili olduğunu düşündükleri sonucuna ulaşılmıştır. Alanyazında öğretmen adaylarının ve bireylerin bilimsel deneyim sağlaması açısından doğa gezilerinin önemli olduğunu belirten çalışmalar bulunmaktadır (Elkins ve Elkins, 2007, s. 128; Farmer, Knapp ve Benton, 2007, s. 35; Torquatia, Cutlerb, Gilkersonb ve Sarvera, 2013, s. 722; Worth, 2010, s. 8). Dolayısıyla elde edilen bu sonucun alanyazınla örtüştüğü söylenebilir. Bu sonucun ortaya çıkması öğretmen adaylarının almış oldukları fen eğitimine yönelik dersleri göz önüne alarak, kalıcı öğrenmelerin gerçekleşmesinde, bilgilerin günlük yaşama aktarılmasında alan gezilerinin etkili olduğunu düşünmelerinden kaynaklanmış olabilir. Bununla birlikte çalışmada ortaya çıkan başka bir sonuç, uygulamalı derslerin yapılmasına yönelik öğretim planlanmasına ilişkindir. Karaçallı (2011, s. 72) tarafından yapılan çalışmada, derslerin teorik olarak yapılmasının, öğrenmenin kalıcılığı üzerine olumsuz etkilerinin olduğunu belirtmiştir. Dolayısıyla öğretmen adayları yine yenilenebilir enerji kaynaklarına iliş̧kin bilgilerin kalıcı hale gelmesi için uygulamalı çalışmaların yapılması gerektiğini ifade etmiş olabilirler. Bazı öğretmen adayları ise konuya ilişkin olarak zihin haritası, altı şapkalı düşünme gibi etkinliklerle, öğrencilere yenilenebilir enerji kaynaklarının öğretilmesi gerektiğini belirtmişlerdir. Alanyazında ise farklı yapılandırıcı öğretim yöntem ve tekniklerinin kullanılmasının öğrenmeyi kolaylaştırdığını belirten çalışmalar yer almaktadır (Rotbain, Marbach-Ad ve Stavy, 2008, s. 52).

\section{"Yenilenebilir Enerji Kaynaklarının Geliştirdiği Okuryazarlık Türleri” Kategorisine Yönelik Tartı̧̧ma ve Sonuç}

Fen bilgisi öğretmen adaylarının yenilenebilir enerji kaynaklarını çevre okuryazarlığı ile ilişskilendirdikleri sonucuna ulaşılmıştır. Alanyazında çevre eğitiminin en önemli amaçları arasında, çevre okuryazarlığı yükssek bireylerin yetiştirilmesi gerektiğini ifade eden çalışmalar yer almaktadır (Disnger ve Roth, 1992; Gahl-Cole, 2007, s. 37; Kışoğlu, 2009; Moseley, 2000, s. 24; Sivek, 2002, s. 156). Bu çalısmanın referans alındığı Marcinkowskiłye (1991, s. 48) göre çevre okuryazarlığı, doğa için kaygılanma ve insanın çevreye olan etkilerini olumlu yönde geliştirme, çevreye ilişkin bilinç sahibi olarak hassasiyet gösterme konularına ilişkin davranış geliştirmeyi içermektedir. Bu sonucun ortaya çıkma nedeni ise öğretmen adaylarının yenilenebilir enerji kaynaklarının çevre teması alında yer alan bir konu olarak düşünmelerinden kaynaklanmış olabilir. Öğretmen adaylarının yenilenebilir enerji kaynaklarını fen okuryazarlığı, medya okuryazarllğı, internet okuryazarllğı ve teknoloji okuryazarlı̆̆ ile ilişkilendirmeleri çalışmanın başka sonuçlarıdır. Köseoğlu ve diğerleri (2003, s. 36) fen okuryazarllğının bireylerin teknoloji ve çevre arasındaki ilişkiyi anlamada önemli olduğunu ifade ederken, Solmaz ve Yılmaz (2012, s. 56) ise medya okuryazarlığının medyada bulunan herhangi bir içeriğe erişebilme amacıyla teknoloji kullanabilme olarak belirtmişlerdir. Dolayısıyla öğretmen adayları da yenilenebilir enerji kaynaklarına yönelik güncel haberleri, gelişmeleri medya üzerinden kolaylıkla erişebilmelerinden dolayı, medya okuryazarlığına değinmiş olabilirler. Destebaşı (2016, s. 325) tarafından yapılan çalışmada, yeni okuryazarlık türlerinin daha çok internet ve dijital alanların gelişimi doğrultusunda ortaya çıktı̆̆ını ifade etmektedir. Dolayısıyla öğretmen adaylarının medyadaki yenilenebilir enerji kaynaklarına ilişkin bilgilere, internet üzerinden kolay erişime ulaşmalarından dolayı internet okuryazarlı̆̆ kavramına değinmiş olabilirler.

\section{“Yenilenebilir Enerji Kaynaklarına İlişkin Öneriler” Kategorisine Yönelik Tartışma ve Sonuç}

Fen bilgisi öğretmen adaylarının konu ile ilgili önerileri incelendiğinde bu önerilerin daha çok bilinçlendirme çalışmalarına yönelik olduğu sonucuna ulaşılmışıı. Alanyazın incelendiğinde ise yenilenebilir enerji kaynaklarına yönelik bireylerin bilinçlendirilmesi gerektiğini ifade eden çalısmaların olduğu tespit edilmiştir (Akçöltekin ve Doğan, 2013; Kyridis ve diğerleri, 2014, s. 144). Öğretmen adayları yenilebilir enerji kaynaklarının güncel olmasına rağmen, bu konuda bireylerin yeterli alg1 sahip olmamasından yola çıkarak bu öneriyi vermiş olabilirler. Çalışmanın başka bir sonucu ise konuya ilişskin uygulamalara daha fazla yer verilmesine yöneliktir. Kavcar (2002, s. 12) nitelikli öğretmenlerin yetiştirilmesi açısından, eğitim fakültelerinde uygulamaya yönelik derslerin işlenmesinin daha doğru olduğunu, Daşdemir ve Doymuş (2016, s. 40) ise uygulamalı etkinliklerin gerçekleştirilmesinin öğrenmedeki kalıcıllğı artırdığını ifade etmektedir. Ayrıca ögretmen adayları çizgi film, reklam tanıtımının yapılması gibi farklı önerileri 
sunmaları, çalışmanın başka sonuçları arasında yer almaktadır. Öğretmen adayları bireylerin küçük yaştan itibaren yaşamı keşfetmeleri ve bu doğrultuda kendilerini şekillendirdiklerini düşünerek, yenilenebilir enerji kaynaklarına ilişkin çizgi filmlerin, küçük yaştaki çocukların algılarını olumlu yönde etkileyeceklerini düşünmelerinden dolayı bu öneriyi vermiş olabilirler. Ayrıca Türkiye Akdeniz bölgesine yaz aylarında sürekli turist çekmektedir. Dolayısıyla öğretmen adayları Türkiye'nin turizm potansiyelini göz önüne alarak jeotermal enerjiye yönelik kurulan kaplıca ve ılıcaların gerekli önemi görmemesinden ve bu merkezlere daha çok yaşlı bireylerin tercih etmesinden dolayı, konuya ilişkin reklamların yapılması gerektiğini düşünmüş olabilirler.

- Bu çalışma fen bilgisi öğretmen adayları ile sınırlıdır. Çevre okuryazarlı̆̆1 her bireyin sahip olması gereken bir okuryazarlık türü olduğu için, farklı bölümdeki öğretmen adayları ile bir çalışma gerçekleştirilebilir.

- Fen bilgisi öğretmenliği bölümünde öğrenimini devam eden ve tüm sınıf düzeyini kapsayan çalışma gerçekleştirilebilir.

- Fen bilgisi öğretmenleri ile fen bilgisi öğretmen adaylarının yenilenebilir enerji kaynaklarına yönelik düşüncelerini belirleyen ve karşılaştırma yapılan farklı bir araştırma gerçekleştirilebilir.

- Bu çalışmada öğretmen adaylarının yenilenebilir enerji kaynaklarına yönelik bilgi düzeylerinin yetersiz olduğuna ilişkin sonuç elde edilmiştir. Bu nedenle yenilenebilir enerji kaynaklarına yönelik bilgi düzeyini artıracak etkinlikler tasarlanabilir.

\section{Etik Beyan}

"Fen Bilgisi Öğretmen Adaylarmm Yenilenebilir Enerji Kaynaklarn Hakkendaki Düsünceleri” başlıklı çalışmanın yazım sürecinde bilimsel, etik ve alıntı kurallarına uyulmuş; toplanan veriler üzerinde herhangi bir tahrifat yapilmamış ve bu çalışa herhangi başka bir akademik yayın ortamına değerlendirme için gönderilmemiştir. $\mathrm{Bu}$ araştırmanın verileri 01.01.2020 tarihinden önce toplandığı için etik kurul kararı zorunluluğu taşımamaktadır.

\section{Kaynakça}

Açıkgöz, C. (2011). Renewable energy education in Turkey. Renewable Energy, 36, 608-611.

Ağaçbiçer, G. (2010). Yenilenebilir enerji kaynaklarmnn Türkiye ekonomisine katkess ve yapılan SWOT analiəler (Yüksek lisans tezi). Çanakkale Onsekiz Mart Üniversitesi Sosyal Bilimler Enstitüsü, Çanakkale.

Akçöltekin, A. ve Doğan, S. (2013). Sınıf öğretmenlerinin yenilenebilir enerji hakkındaki tutumlarının belirlenmesi. International Journal of Social Science, 6(1), 143-153.

Akınoğlu, O. ve Sar1, A. (2007). İlköğretim programlarında çevre eğitimi. M.Ü. Atatürk Eğitim Fakïlltesi Eğitim Bilimleri Dergisi, 30, 5-29.

Aktamış, H. (2011). Determining energy saving behavior and energy awareness of secondary school students according to socio-demographic characteristics. Educational Research and Reviews, 6(3), 243-250.

Arastman, G., Öztürk Fidan, İ. ve Fidan, T. (2018). Nitel araştırmada geçerlik ve güvenirlik: kuramsal bir inceleme. YYÜ Ë̈̆itim Fakïltesi Dergisi, 15(1), 37-75.

Ataman, A.R. (2007). Türkije'de yenilenebilir enerji kaynaklarn (Yüksek Lisans Tezi). Ankara Üniversitesi Sosyal Bilimler Enstitüsü, Ankara.

Balkan Kıyıcı, F. ve Atabek Yiğit, E. (2010). Sınıf duvarlarının ötesinde fen eğitimi: Rüzgar santrallerine teknik gezi. International Online Journal of Educational Sciences, 2(1), 225-243.

Bang, H. K., Ellinger, A. E., Hadjimarcou, J. ve Traichal, P. A. (2000). Consumer concern, knowledge, belief, and attitude toward renewable energy: An application of the reasoned actiontheory. Psychology and Marketing, 17(6), $449-468$.

Başkale, H. (2016). Nitel araştırmalarda geçerlik, güvenirlik ve örneklem büyüklüğünün belirlenmesi. DEUHFED, 9(1), 23-28.

Bayraç, H. N. (2010). Enerij kullanımının küresel ssınmaya etkisi ve önleyici politikalar. Eskişehir Osmangazi Üniversitesi Sosyal Bilimler Dergisi,11(2), 229-260.

Benzer, E., Karadeniz Bayrak, B., Dilek Eren, C. ve Gürdal, A. (2014). Knowledge and opinions of teacher candidates about energy and energy resources. International Online Journal of Educational Sciences, 6(1), 243-257.

Bhattacharya, S. C. (2001). Renewable energy education at the university level. Renewable Energy, 22, 91-97.

Biylklı, D. (2018). Ögretmen ve ögretmen adaylarmn yenilenebilir enerji kaynaklar hakkendaki görïslerinin incelenmesi (Yüksek lisans tezi) Mersin Üniversitesi Eğitim Bilimleri Enstitüsü, Mersin.

Bodur, G. ve Şenyuva, E. (2013). Üniversite öğrencilerinin hidroelektrik enerji santrallerine (HES) ilişkin görüşleri ile çevreye yönelik tutumları arasındaki ilişki. Cumburiyet International Journal of Education, 2(4), 27-38. 
Bozdoğan, A. E. ve Yalçın, N. (2006). Bilim merkezlerinin ilköğretim öğrencilerinin fene karş1 ilgi düzeylerinin değişmesine ve akademik başarılarına etkisi: Enerji parkı. Ege Ë̆itim Dergisi, 7(2), 95-114.

Bozdoğan, A. E. ve Yiğit, D. (2014), Öğretmen adaylarının alternatif enerji kaynaklarına yönelik görüşlerinin farklı değişkenler açısından incelenmesi. Elektronik Eğitim Bilimleri Dergisi, 3(6), 113-130.

Bozkurt, A. U. (2008). Yenilenebilir enerji kaynaklarmın enerji verimlilï̆i açısından değerlendirilmesi (Yüksek Lisans Tezi). Dokuz Eylül Üniversitesi Sosyal Bilimler Enstitüsü, İzmir.

Cansaran, A. ve Yıldırım, C. (2010). Çevre bilimi ile ilgili başlıca terimler ve kavramlar. İçinde O. Bozkurt (Edt.). Çevre Eğitimi (ss. 1-19). Ankara: Pegem Akademi.

Cebesoy, Ü. B. ve Karışan, D. (2017). Fen Bilgisi öğretmen adaylarının yenilenebilir enerji kaynaklarına yönelik bilgilerinin, tutumlarının ve bu kaynakların öğretimi konusundaki öz-yeterlik algılarının incelenmesi. YYÜ Ĕ̈itim Fakültesi Dergisi, 14(1), 1377-1415.

Creswell, J. W. (2007). Qualitative inquiry and research design: Choosing among five traditions. California: Sage.

Çakırlar, E. (2015). Ortä̈gretim ögrencilerinin yenilenebilir enerji kaynaklar konusundaki farkindahk düzeylerinin belirlenmesi. (Yüksek Lisans Tezi). Hacettepe Üniversitesi Eğitim Bilimleri Enstitüsü, Ankara.

Çelikler, D. ve Kara, F. (2011). İlköğretim matematik ve sosyal bilgiler ögretmen adaylarmm yenilenebilir enerji konusundaki farkindalkelar. 2nd International Conference on New Trends in Education and Their Implications 27-29 Nisan, Antalya.

Çelikten, M. Şanal, M. ve Yeni, Y. (2006). Öğretmenlik mesleği ve özellikleri. Sosyal Bilimler Enstitüsü Dergisi 19(2), 207-237.

Daşdemir, İ., ve Doymuş, K. (2016). Fen ve teknoloji dersinde animasyon kullanımının öğrencilerin akademik başarılarına, öğrenilen bilgilerin kalıcılığına ve bilimsel süreç becerilerine etkisi. Pegem Ĕgitim ve Öğretim Dergisi, 2 (3), 33-42.

Danijela, L., Popovski, K., Gecevska, V., Vasilevska, S. P. ve Tesic, Z. (2011). Analysis of the opportunities and challenges for renewable energy market in the Western Balkan Countries. Renew Sustain Energy, 15, 3187-3195.

Destebaşı, F. (2016). Yeni okuryazarlıklar: tanımı, kapsamı ve teorik ilkeleri. Turkish Studies, International Periodical for the Languages, 895910.https://www.researchgate.net/publication/301284881_NEW_LITERACIES_DEFINITION_SCOPE_A ND_THEORETICAL_UNDERPINNINGS_YENI_OKURYAZARLIKLAR_TANIMI_KAPSAMI_VE_T EORIK_ILKELERI adresinden 15.05.2019 tarihinde erișilmiştir.

Disinger, J. F. ve Roth, C. E. (1992). Environmental literacy. Clearinghouse for Science, Mathematics and Environmental Education (CSMEE), Ohio State University.

Elder, J. L. (2003). A field guide to environmental literacy: Making strategic investments in environmental education. Rock Spring, Georgia: North American Association for Environmental Education.

Elkins, J. T. ve Elkins, N. M. L. (2007). Teaching geology in the field: significant geoscience concept gains in entirely field-based inductory geology courses, Journal of Geoscience Education, 55(2), 126-132.

Ertaş, H., Şen, A. İ. ve Parmasızoğlu, A. (2011). Okul dışı bilimsel etkinliklerin 9. sınıf öğrencilerinin enerji konusunu günlük hayatla ilişkilendirme düzeyine etkisi. Necatibey Eğitim Fakültesi Elektronik. Fen ve Matematik. Eğitimi Dergisi, 5(2), 178-198.

Farmer, J., Knapp, D. ve Benton G. M. (2007). An elementary school environmental education field trip: long-term effects on ecological and environmental knowledge and attitude development. The Journal of Environmental Education, 38(3), 33-42.

Fırat, A., Sepetçioğlu, H. ve Kiraz, A. (2012). Öğretmen adaylarının yenilenebilir enerjiye ilişkin tutumlarının incelenmesi. Hacettepe Üniversitesi Ë̆itim Fakültesi Dergisi, 1, 216-224.

Gahl-Cole, A. (2007). Expanding the field: revisiting environmental education principles through multidisciplinary frameworks. The Journal of Environmental Education, 38(2), 35-44.

Gençoğlu, M. T. (2012). Yenilenebilir enerji kaynaklarının Türkiye açısından önemi http://www.solaracademy.com/menuis/Yenilenebilir-Enerji-Kaynaklarinin-Turkiye-Acisindan-Onemi.005039.pdf adresinden 11.05.2019 tarihinde erişilmiştir.

Göçer, A. (2013). Türkçe öğretmeni adaylarının dil kültür ilişkisi üzerine görüşleri: Fenomenolojik bir araştırma. Eržincan Üniversitesi Ë̈itim Fakültesi Dergisi, 15(2), 25-38.

Gupta, C. (2003). Role of renewable energy technologies in generating sustainable livelihoods. Renew Sustain Energy Rev, 7, 155-174.

Halder, P., Pietarinen, J., Nuutinen, S. ve Pelkonen, P. (2010). Young citizens' knowledge and perceptions of bioenergy and future policy implications. Energy Policy, 38(6), 3058-3066.

Halder, P., Havu-Nuutinen, S., Pietarinen, J. ve Pelkonen, P. (2011). Bio-energy and youth: Analyzing the role of school, home, and media from the future policy perspectives. Applied Energy, 88, 1233-1240.

Hurley, M. (2006). Field trips as cognitive motivators for high level science learning. American biology teacher, 68(6), 6166.

Ilgar, R. (2007). Çevre eğitiminde yaygın eğitimin rolü ve önemi. Ondokuฉ Mayıs Üniversitesi Eğitim Fakültesi Dergisi, 23 , 38-50.

Kaldellis, J. K., Kapsali, M. ve Katsanou, E. (2012). Renewable energy applications in Greece-What is the public attitude. Energy Policy, 47, 37-48. 
Karaçall, S. (2011). İlköğretim 4. sinff fen ve teknoloji dersinde proje tabanl ögrgenme yönteminin akademik başarya, tutuma ve kahclly̆ga etkisi (Yüksek lisans tezi). Mehmet Akif Ersoy Üniversitesi Sosyal Bilimler Enstitüsü, Burdur.

Karakaya Cırıt, D. (2017). Fen bilgisi öğretmen adaylarının yenilenebilir enerji kaynaklarına ilişkin bilgileri. Turkish Journal of Educational Studies, 4(3), 21-43.

Karanfil, F. (2009). Enerji-büyüme-çevre: Türkiye üçgenin neresinde? Uluslararası İlişkiler, 5(20), 1-26.

Karasar, N, (2013). Bilimsel araștırma yöntemi. Ankara: Nobel yayıncılık.

Karışan, D. ve Topçu, M. S. (2016). Contents exploring the preservice science teachers' written argumentation skills: The global climate change issue. International Journal of Environmental and Science Education 11(6), 1347-1363.

Karytsas, S. ve Theodoropoulou, H. (2014). Socioeconomic and demographic factors that influence publics awareness on the different forms of renewable energy sources. Renewable Energy, 71, 480-485.

Kavcar, C. (2002). Cumhuriyet döneminde dal öğretmeni yetiştirme. Ankara Üniversitesi Ë̆itim Bilimleri Fakültesi Dergisi, 35, 1-13.

Koroneos, C., Spachos, T. ve Moussiopoulos, N. (2003). Energy analysis of renewable energy sources. Renewable energy, 28(2), 295-310.

Köseoğlu, F., Atasoy, B., Kavak, N., Akkuş, H., Budak, E., Tümay, H., Kadayıfçı, H. ve Taşdelen, U. (2003). Yapılandırı ögrenme ortamı için: Bir fen ders kitabı nasıl olmalı. Asil Yayın Dağıtım: Ankara.

Kumbur, H., Özer, Z., Özsoy, H. D. ve Avci, E. D. (2005). Türkiye'de geleneksel ve yenilenebilir enerji kaynaklarının potansiyeli ve çevresel etkilerinin karşılaştırılması. III. Yenilenebilir Enerji Kaynaklar Sempozyumu Bildiriler Kitabı, (ss. 19-21), Mersin: Türkiye.

Kyridis, A., Avramidou, M., Zagkos, C., Christodoulou, A. ve Pavli-Korre, M. (2014). Who is the ideal teacher? Greek pre-service teachers express their views about the characteristics of the perfect teacher. Journal for Educators, Teachers and Trainers, 5(2), 143-159.

Lay, Y. F., Khoo, C. H., Treagust, D. F. ve Chandrasegaran, A. L. (2013). Assessing secondary school students' understanding of the relevance of energy in their daily lives. International Journal of Environmental and Science Education, 8(1), 199-215.

Liarakou, G., Gavrilakis, C. ve Flouri, E. (2009). Secondary school teachers knowledge and attitudes towards renewable energy sources. Journal of Science Education and Technology, 18(2), 120-129.

Marcinkowski, T. (1991). Methods and techniques for evaluating environmental education. Paris: UNESCO.

Merriam, B., S. (2013). Nitel araştırma desen ve uygulama için bir rehber. Ankara: Nobel Yayınları.

Miles, M. B. ve Huberman, A. M. (2016). An expanded sourcebook qualitative data analysis. California: Sage Publications.

Moseley, C. (2000). Teaching for environmental literacy. The Clearing House, 74(1), 23-24.

Okur Berberoğlu, E. ve Uygun, S. (2013). Sınıf dışı eğitimin dünyadaki ve Türkiye'deki gelişiminin incelenmesi. Mersin Üniversitesi Eğitim Fakültesi Dergisi, 9(2), 32-42.

Öztürk, H. (2008). Yenilenebilir enerji kaynaklar ve kullanım. Ankara: Teknik Yayınevi.

Patton, M. Q. (2018). Qualitative research evulation methods. California: Sage.

Perkins, D. (1999). The many faces of constructivism. Educational Leadership, 57(3), 6-11.

Rotbain, Y., Marbach-Ad, G. ve Stavy, R. (2008). Using a computer animation to teach high school molecular biology. Journal of Science Education Technology, 17, 49-58.

Saatçioğlu, C. ve Küçükaksoy, İ. (2004). Türkiye ekonomisinin enerji yoğunluğu ve önemli enerji taşıma projelerinin ekonomiye etkisi. Dumlupınar Üniversitesi Sosyal Bilimler Dergisi, 11, 19-39.

Saraç, H. ve Bedir, E. (2014). Sınıf öğretmenlerinin yenilenebilir enerji kaynakları ile ilgili algılamaları üzerine nitel bir çalışma. KHO Bilim Dergisi, 24(1), 19-45.

Sathaye, J., Lucon, O., Rahman, A., Christensen, J., Denton, F. ve Fujino, J. (2011). Renewable energy in the context of sustainable development. USA: Cambridge University Press.

Sivek, D. J. (2002). Environmental sensitivity among Wisconsin High School students. Environmental Education Research, 8(2), 155-170.

Smati, B. (2004). Environmental education in Tunisia. Sustainable Mediterranean, 34, 7-8.

Solmaz, B. ve Yılmaz, R. A. (2012). Medya okuryazarlığı araştırması ve Selçuk Üniversitesi’nde bir uygulama. Selçuk Iletisim, 7(3), 56-61.

Tanrıverdi, B. (2009). Sürdürülebilir çevre eğitimi açısından ilköğretim programlarının değerlendirilmesi. Eğitim ve Bilim, 34(151), 89-103.

Torquatia, J., Cutlerb K., Gilkersonb, D. ve Sarvera, S. (2013). Early childhood educators' perceptions of nature, science, and environmental education. Early Education and Development, 24(5), 721-743.

Töman, U. ve Odabaşı Çimer, S. (2013). Enerji kaynakları ve enerji depolanması kavramlarının farklı öğrenim seviyelerinde öğrenilme durumunun araştırllması. Dicle Üniversitesi Ziya Gökalp Eğitim Fakültesi Dergisi, 21, 47-68.

Turan, S. (2006). Yenilenebilir enerji kaynaklar. Arastırma raporlar. Konya: Konya Ticaret Odası Yayınları.

Upreti, B. R. (2004). Conflict over biomass energy development in the united kingdom: some observations and lessons from england and wales. Energy Policy, 32, 785-800.

Whitman, C. (2013). Sorry, but Renewable Energy Doesn't Always Work. The Wall Street Journal. https://www.wsj.com/articles/the-biggestmisconceptions- people-have-about-renewable-energy-1380066859 adresinden 09.05.2019 tarihinde erişilmiştir.

Worth, K. (2010). Science in early childhood classrooms: content and process. http:/ / ecrp.illinois.edu/beyond/seed/worth.html adresinden 11.05.2019 tarihinde erişilmiştir. 
Varınca, K. B. ve Gönüllü, M. T. (2006). Türkiye'de güneş enerjisi potansiyeli ve bu potansiyelin kullanım derecesi, yöntemi ve yaygınlığı üzerine bir araştırma. I. Ulusal Güneş ve Hidrojen Enerjisi Kongresi, 21-23 Haziran 2006, ESOGÜ, Eskişehir.

Yangın, S. ve Filik İşçen, C. (2013). Çevre eğitimi: mevcut durum ve yaşanan sorunlar (Recep Tayyip Erdoğan Üniversitesi ve Eskişehir Osmangazi Üniversitesi Örneği). Elektronik Sosyal Bilimler Dergisi, 12(46), 131-150.

Yıldırım, A. ve Şimşek, H. (2013). Sosyal bilimlerde nitel araştırma yöntemleri. Ankara: Seçkin Yayınları.

Zyadin, A., Puhakka, A., Ahponen, P., Cronberg, T. ve Pelkonen, P. (2012). School students' knowledge, perceptions, and attitudes toward renewable energy in Jordan. Renewable Energy, 45, 78-85.

Zeray, C. (2010). Renewable energy sources (Yüksek lisans tezi). Çukurova Üniversitesi Fen Bilimleri Enstitüsü, Adana.

\section{EXTENDED ABSTRACT}

Renewable energy is an energy that can last for generations smoothly without disturbing the ecological balance and causing environmental damage that cannot be compensated (Firat, Sepetçioğlu, \& Kiraz, 2012, p. 1213). These are energy resources emphasizing the concept of clean-environmentally friendly and sustainable living (Upreti, 2004, p. 786). Environmental pollution can be minimized and significant contributions will be made to the countries' future with the widespread and effective use of renewable energy resources. The identification of the individuals' views regarding renewable energy resources will provide the necessary knowledge for raising awareness towards taking more robust steps for the future. Teachers are among the individuals who have responsibilities and who are considered significant in raising individuals sensitive to their environment, who know what renewable energy is, their benefits to humanity, their usage areas and who have sufficient knowledge about energy resources defined as environmentally friendly (Liarakou, Gavrilakis, \& Flouri, 2009, p. 121). Teachers learn about renewable energy resources at the undergraduate level in the education faculty within the scope of the environmental education course. Pre-service teachers will reflect their positive thoughts on renewable energy to their students when they start teaching (Smati, 2004, p. 7). Thus, this research is expected to contribute to the pre-service science teachers' positive thinking and attitude towards the renewable energy resources when they start their professional life.

Upon analyzing the relevant literature, various studies were conducted on renewable energy resources. These studies tried to examine the pre-service science teachers' knowledge levels for renewable energy resources (Karakaya Cir1t, 2017, p. 23), to transfer knowledge about the subject to daily life (Ertaş, Şen, \& Parmasızoğlu, 2011, p. 181), and to determine renewable energy awareness (Çakırlar, 2015, p. 4). However, there is a limited number of studies conducted qualitatively with pre-service science teachers to determine their views on renewable energy resources, and these studies mostly focused on the examples of renewable energy sources, their advantages and sustainable development (Biyıkl1, 2018, p. 2; Saraç, \& Bedir, 2014, p. 20). There is no such study specifically published on the relationship of the resources with the environment, the significance and use of the renewable energy resources in Turkey, whether there was sufficient knowledge about these resources as a society, the role of teachers in the promotion of resources along with its relation to literacy. Therefore, this research is considered to contribute qualitatively to the literature. In this regard, an answer to the question "What are the pre-service science teachers' views towards renewable energy resources?" was sought.

The research deployed a phenomenological design, one of the qualitative research designs, since it aims to determine the pre-service teachers' views on renewable energy resources in and their past experiences regarding the subject. The working group consisted of 8 pre-service science teachers who study science education at the education faculty of a state university in the Mediterranean region during the spring term of 2018-2019 academic year and who were selected by criteria sampling, which is among the purposive sampling methods. The research employed a "Renewable Energy Resources Interview Form" prepared by the researchers as a data collection tool. During data collection process, volunteer students were determined and they were presented information about the subject and aim of the research. The data were collected between 17/04/2019 and 24/04/2019. Content and descriptive analysis were used during data analysis. The data were analyzed in the order of questions, the word or words identified as codes were underlined, categories were identified by bringing all the codes together, and all categories were analyzed under the theme of renewable energy resources. For instance, the concepts of "geothermal energy, wind energy and hydraulic energy" were determined as codes and these codes were gathered under the "category of examples for renewable energy resources". In addition, the questions in the data collection tool were taken into account during category formation process. 
The research results revealed that the pre-service science teachers defined renewable energy resources as continuing, environmentally friendly and long-term resources. The majority of the pre-service teachers were found to have insufficient perception towards the subject. Besides, the pre-service teachers stated that solar and wind energy is the most useful and available resource among the renewable energy resources. The pre-service teachers also noted that they did not participate in any activities related to renewable energy resources, and that that the functions of renewable energy resources were to protect nature, to make life easier, to meet the increasing population's needs. While the pre-service science teachers expressed the positive aspects of renewable energy resources as being economical, harmless to the environment, clean and having no risk of exhaustion; the negative aspects were investment cost, occupation of agricultural lands, adverse effect on the climate and waste water generation. Referring to the teachers' roles related to these resources, the pre-service science teachers explained them as raising students' awareness, being role models, supporting projects, and developing positive attitudes. Moreover, the pre-service teachers referring that renewable energy resources are a global situation and that the knowledge was insufficient recommended a university-wide course on this subject. They also suggested that field trips, mind map, poster design and competitions should be held for teaching renewable energy resources. Having mentioned that renewable energy resources develop some types of literacy, the participants noted environment, science, technology, media and internet literacy. Last but not least, the pre-service science teachers proposed a suggestion on the training of qualified people by preventing brain drain. 